\title{
Volcaniclastic stratigraphy of Gede Volcano, West Java, Indonesia: How it erupted and when
}

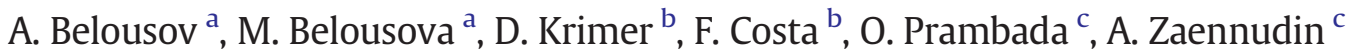 \\ a Institute of Volcanology and Seismology, Russia \\ ${ }^{\mathrm{b}}$ Earth Observatory of Singapore, Singapore \\ c Center for Volcanology and Geological Hazard Mitigation, Indonesia
}

\section{A R T I C L E I N F O}

\section{Article history:}

Received 4 November 2014

Accepted 19 May 2015

Available online 29 May 2015

\section{Keywords:}

Volcaniclastic deposits

Volcanic eruption

Gede Volcano

Eruptive history

Radiocarbon dating

Magma mixing

\begin{abstract}
A B S T R A C T
Gede Volcano, West Java (Indonesia), is located $60 \mathrm{~km}$ south of Jakarta within one of the regions with highest population density in the world. Therefore, knowledge of its eruption history is necessary for hazard evaluation, because even a small eruption would have major societal and economic consequences. Here we report the results of the investigation of the stratigraphy of Gede (with the focus on its volcaniclastic deposits of Holocene age) and include 23 new radiocarbon dates. We have found that a major part of the volcanic edifice was formed in the Pleistocene when effusions of lavas of high-silica basalt dominated. During this period the volcano experienced large-scale lateral gravitational failure followed by complete reconstruction of the edifice, formation of the summit subsidence caldera and its partial refilling. After a repose period of $>30,000$ years the volcanic activity resumed at the Pleistocene/Holocene boundary. In the Holocene the eruptions were dominantly explosive with magma compositions ranging from basaltic andesite to rhyodacite; many deposits show heterogeneity at the macroscopic hand specimen scale and also in the minerals, which indicates interactions between mafic (basaltic andesite) and silicic (rhyodacite) magmas. Significant eruptions of the volcano were relatively rare and of moderate violence (the highest VEI was 3-4; the largest volume of erupted pyroclasts $0.15 \mathrm{~km}^{3}$ ). There were 4 major Holocene eruptive episodes ca. 10,000, 4000, 1200, and $1000 \mathrm{yr}$ BP. The volcanic plumes of these eruptions were not buoyant and most of the erupted products were transported in the form of highly concentrated valley-channelized pyroclastic flows. Voluminous lahars were common in the periods between the eruptions. The recent eruptive period of the volcano started approximately 800 years ago. It is characterized by frequent and weak VEI 1-2 explosive eruptions of Vulcanian type and rare small-volume extrusions of viscous lava. We estimate that during last 10,000 years, Gede erupted less than $0.3 \mathrm{~km}^{3}$ DRE (Dense Rock Equivalent) of magma. Such small productivity suggests that the likelihood of future large-volume (VEI $\geq 5$ ) eruptions of the volcano is low, although moderately strong (VEI 3-4) explosive eruptions capable of depositing pyroclastic flows and lahars onto the NE foot of the volcano are more likely.
\end{abstract}

(c) 2015 Elsevier B.V. All rights reserved.

\section{Introduction}

Gede Volcano (2958 masl - meters above sea level), sometimes also spelled as Gedeh, together with the adjacent Pangrango Volcano (3019 masl) form a large (base diameter $30 \mathrm{~km}$ ) volcanic massif, just $60 \mathrm{~km}$ south of the Indonesian capital Jakarta, West Java (Figs. 1 and 2 ). The volcano belongs to the Sunda arc, the volcanism of which is associated with the subduction of the Indo-Australian plate beneath the Eurasian plate at rate of approximately $6 \mathrm{~cm} / \mathrm{y}$. While Pangrango has no historically recorded eruptions, Gede is one of the more active volcanoes in Indonesia: 26 eruptions were reported since 1747; the last of them occurred in 1947-1957 (Siebert et al., 2010; Smithsonian database at www.volcano.si.edu/volcano.cfm?vn $=263060$; Supplementary Fig. 1). The earliest reports of Gede eruptions are very brief and allow only inferring that those eruptions were mild and mostly explosive. The 1747-1748 and 1840 eruptions apparently were relatively important and possibly included lava extrusions. Photos and descriptions of the 20th century eruptions suggest that they consisted of sporadic ash- and bomb-laden explosions akin to Vulcanian type in a broad sense (according to the definition given in Clarke et al., 2015). Modern activity of the volcano includes persistent solfataric activity in the summit crater (with temperatures $150-200{ }^{\circ} \mathrm{C}$ ) and periodic seismic swarms possibly indicating shallow intrusions of magma in 1990, 1991, 1992, 1995, 1996, 1997, 2000, 2007, 2010, 2011, and 2012 (Suantika et al., 1999; Zaennudin, 2008; Hidayat et al., 2012).

Due to the fertile volcanic soil and warm, humid climate, land at the ring plain of Gede has one of the highest population densities in the world. Population data for 1990 indicate an average of 1085 persons per $\mathrm{km}^{2}$ with total population of 29.4 million around the volcano (Small and Naumann, 2001). An almost uninterrupted belt of towns and villages occupies the elevations up to 1500 masl., while individual households and gardens climb up to 1800 masl. Higher up the volcano is covered by the 
famous rain forest of Gede-Pangrango National Park, which is visited by numerous tourists, many of whom camp in the summit area. Considering all this, the reconstruction of eruptive history and accurate hazard assessment of the Gede-Pangrango volcanoes is an important objective. The Volcanological Survey of Indonesia mapped the distributions of volcaniclastic deposits (Situmorang and Hadisantono, 1992) and composed a volcanic hazard map of the area (Hadisantono et al., 2006). However, this work was lacked radiocarbon dating and thus only a general stratigraphic scheme for the volcano could be proposed.

In this paper we report the results of investigation of stratigraphy of Gede with the focus on its volcaniclastic deposits of the Holocene age. We also give the basic petrological and geochemical information that allows understanding the main magmatic processes involved in the evolution of Gede as well as potential eruption triggers. We visited multiple outcrops of the deposits and obtained 23 new radiocarbon dates for the area and as a result the timing and character of activity of Gede in Holocene time has been revealed.

\section{General geology and geomorphology of Gede Volcano}

The first descriptions of geology of Gede Volcano were made by Verbeek and Fennema (1896), Taverne (1926), Van Bemmelen (1949), Petroeschevsky and Klompe (1951), and Neumann van Padang (1951). Data on modern petrography, mineralogy, and geochemistry were published by Davidson et al. (2007), Handley et al. (2010, 2011) and Dempsey (2013).

The edifice of the volcano (Fig. 1) consists of 3 major parts having different ages (from old to young):

(1) Main stratocone (called Gumuruh) with 1.8-km-wide summit caldera;

(2) Intra-caldera cone (Gede proper) with 900-m-wide summit crater;

(3) Intra-crater infill composed of lava dome with 3 small explosive craters on its top (below we informally call them "explosive funnels" to distinguish from much larger summit crater of the volcano).

The Gumuruh stratocone has relative elevation $2400 \mathrm{~m}$ above the volcanic base. Its strongly truncated edifice (with a volume of the order of $100 \mathrm{~km}^{3}$ ) comprises more than $95 \%$ of the total volume of the volcano (Fig. 1). The upper-middle slopes of Gumuruh are covered by thick lava flows and have only a few outcrops. The internal structure of the cone can be inferred mostly from the geology of the voluminous South-Eastern (SE) debris avalanche deposit formed by ancient gravitational collapse of the volcano (MacLeod, 1989; Situmorang and Hadisantono, 1992). The scar of the collapse is completely refilled with younger volcanic products and not visible now. The SE avalanche

a

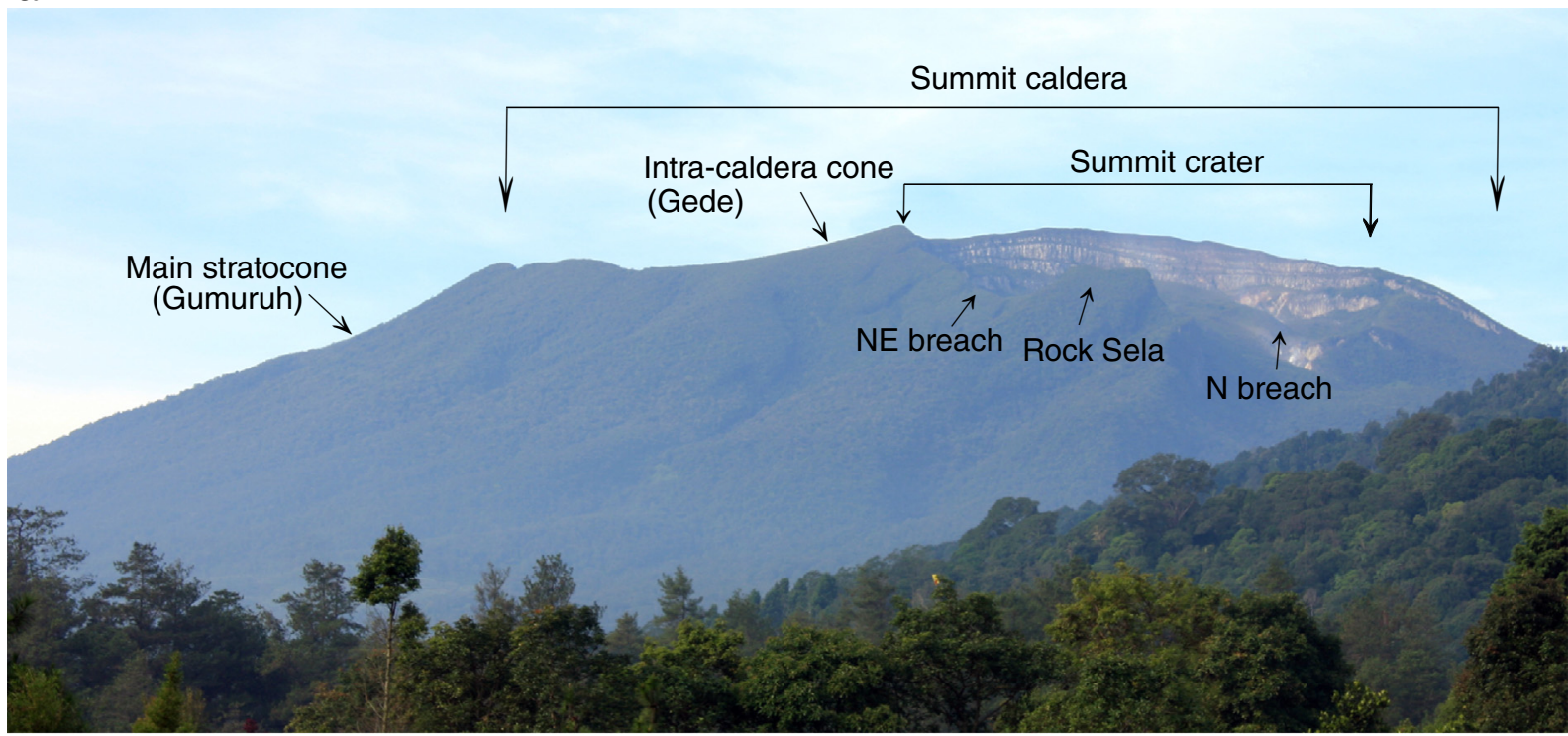

b

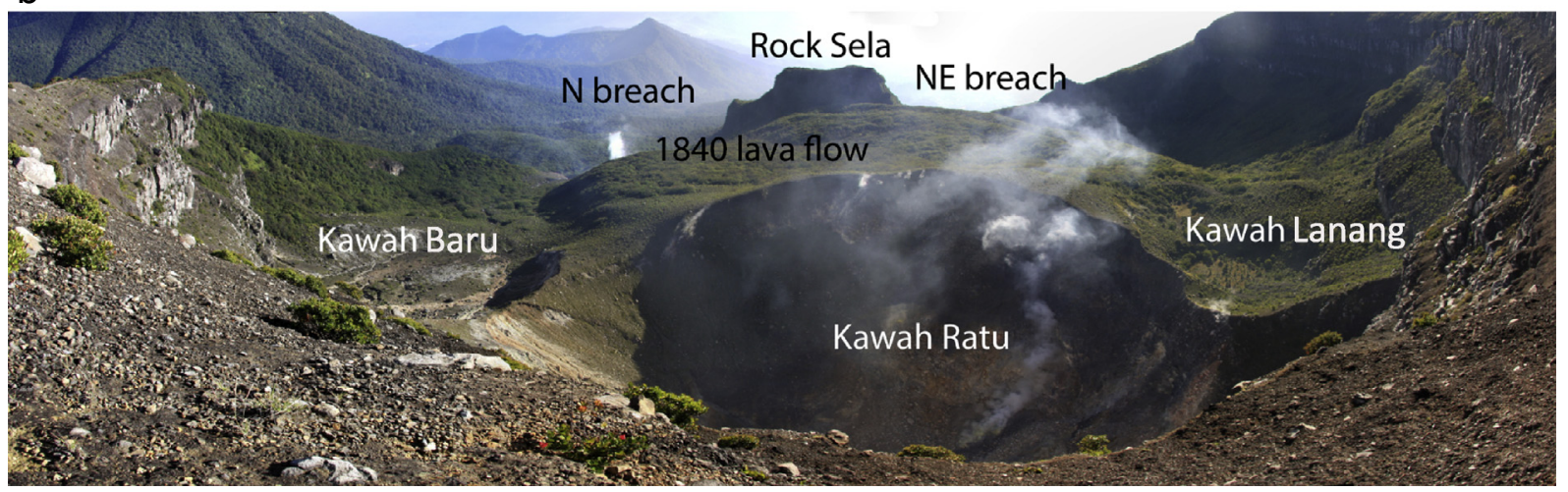

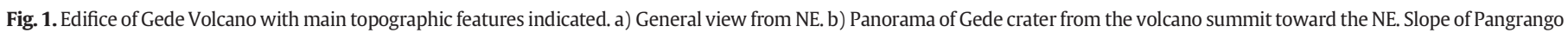
Volcano is visible in the upper left corner. Photos by A. Belousov. 
a

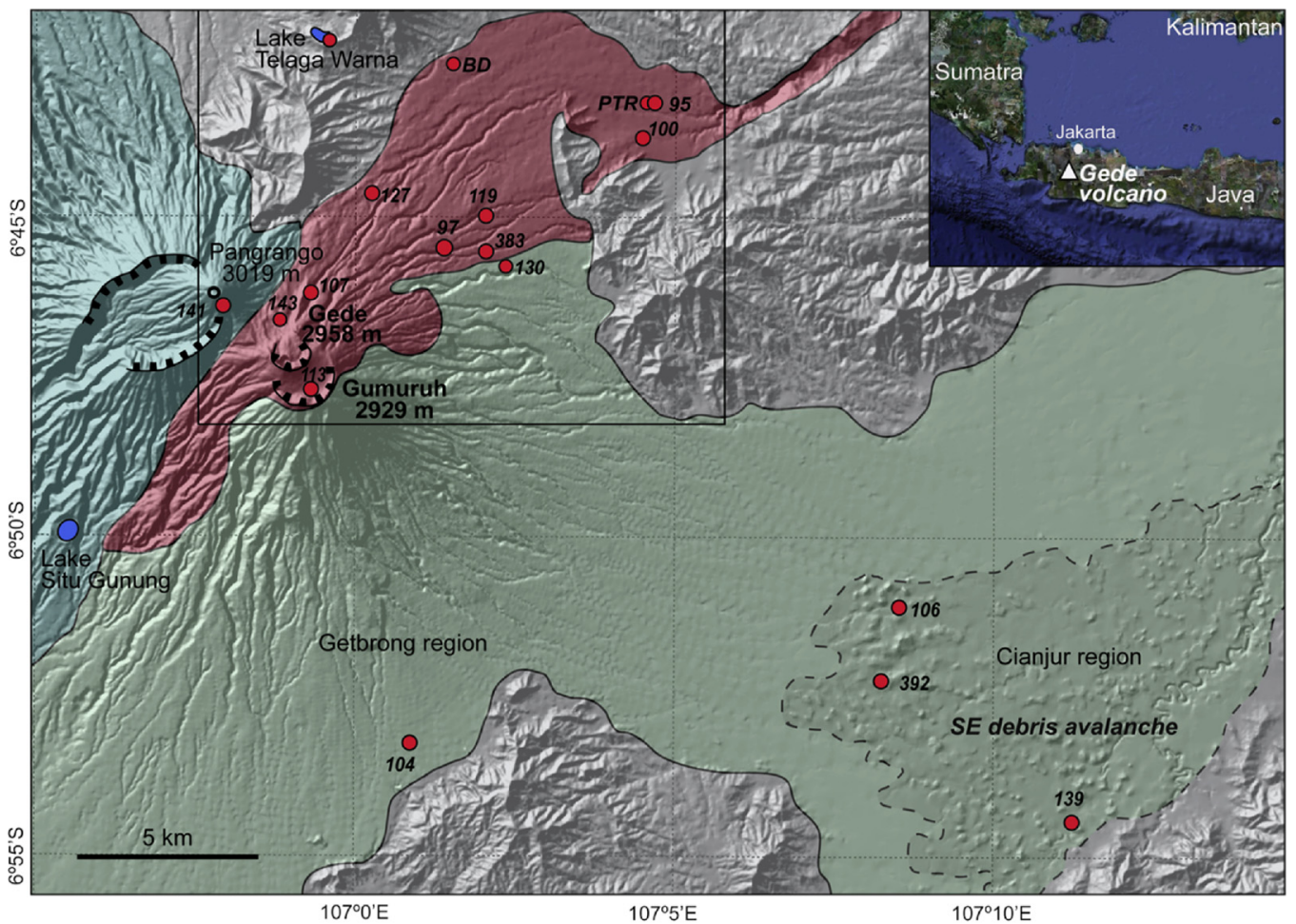

b

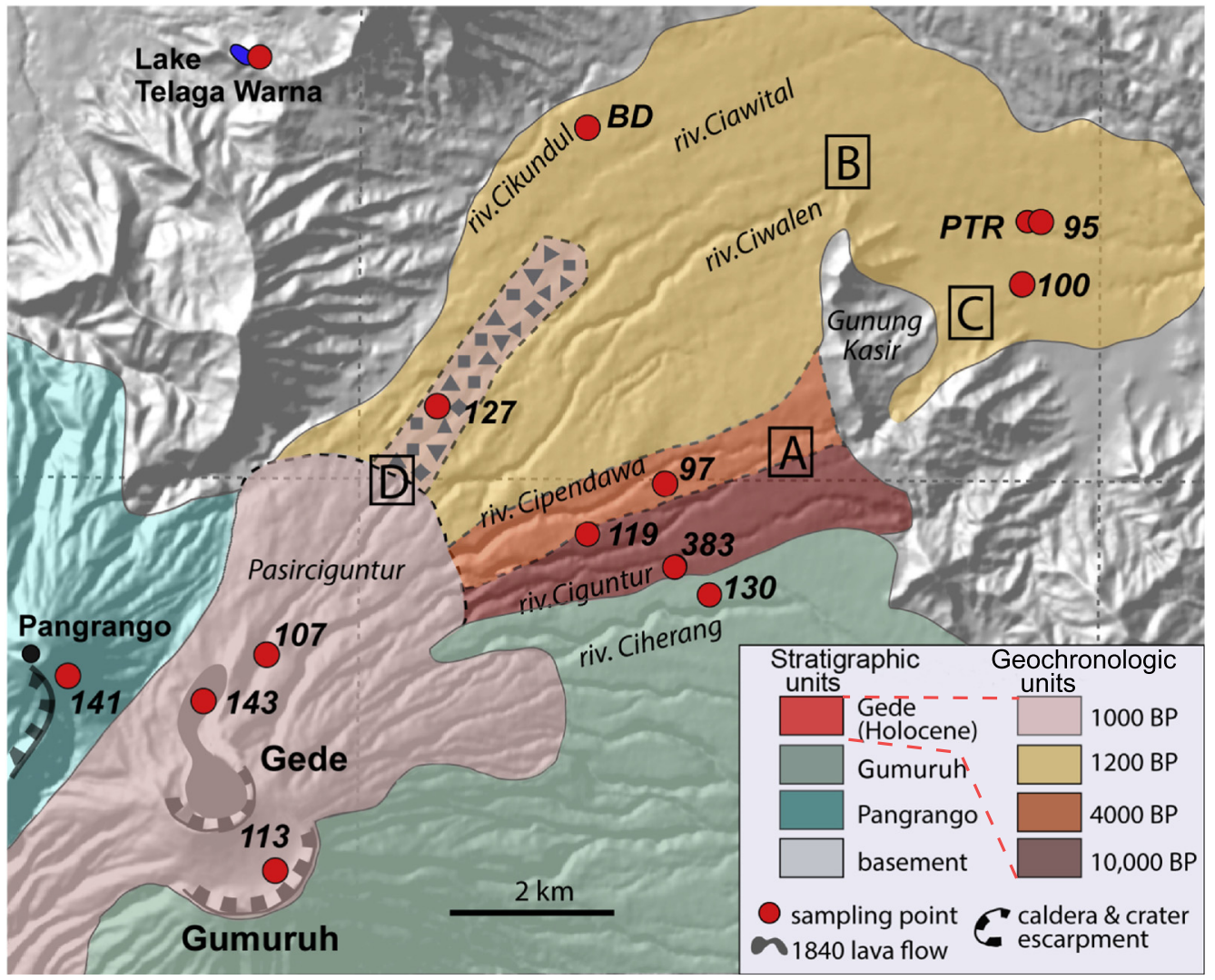

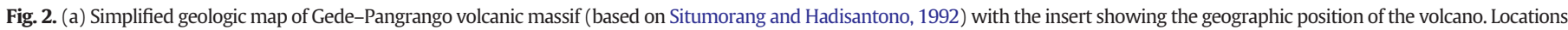

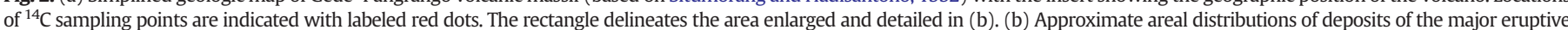

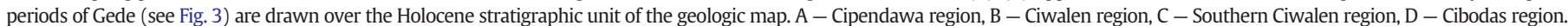
Polygons mark the NE debris avalanche deposit. 




deposit covers more than $250 \mathrm{~km}^{2}$ on the lower south-eastern flank of the volcano in Cianjur region (Fig. 2a). It traveled at least $35 \mathrm{~km}$, and had volume of no less than $10 \mathrm{~km}^{3}$. Numerous large (up to $30-50 \mathrm{~m}$ in height) conical hummocks of the deposit are extensively mined for construction materials and thus are well exposed. They are composed of block facies represented by variously fragmented and deformed former massive lava flows of high-silica basalts and their scoriaceous autobreccias. In the distal area, a significant part of the debris avalanche deposit between the hummocks is composed of mixed facies containing multiple fragments of picked-up wood. Material of the debris avalanche shows that the ancient cone of Gumuruh (before the gravitational collapse) was composed mostly of thick blocky lava flows morphologically similar to those exposed on the cone surface. No pyroclastic deposits associated with the gravitational collapse have been found, i.e., no evidence has been found that the sector collapse triggered an eruption.

The southern foot of the volcano (Getbrong region) is covered by a large fluvial fan composed mostly of deposits of lahars (Fig. 2a). The thickness of the fan deposit (well-exposed in multiple quarries) exceeds $50 \mathrm{~m}$. The fan was possibly deposited when the avalanche scar existed on the south-eastern slope of Gumuruh.

${ }^{14} \mathrm{C}$ dating of wood incorporated in both the debris avalanche deposit and the volcaniclastic fan (locations \#139 and 104) provided ages beyond the limit for ${ }^{14} \mathrm{C}$ analysis, and thus they are older than ca. 43,500 yr BP. The lowermost sections of thick (3-6 m) red laterite soils covering the deposits of the SE debris avalanche (locations \#106 and 392) provided ages of approximately 13,000 yr BP (Fig. 2a, Table 1). Similar soils covering slopes of Gumuruh in many other locations confirm the Middle-Late Pleistocene age of Gumuruh stratocone.

The summit caldera of Gumuruh has a horseshoe shape that is opened toward the NNE (Fig. 1). We did not find any debris avalanche deposit of sufficient volume in the corresponding sector of the volcano that could explain formation of the caldera by lateral gravitational collapse. Most probably this caldera was produced by vertical subsidence that was slightly shifted to the north from the cone axis. The voluminous pyroclasts that could be associated with formation of the caldera have not been found, thus we think the subsidence could be associated with voluminous flank eruption(s) of lava (there are several large lava flows on the slopes of Gumuruh). The age of the caldera is not known, but it should be somewhat younger than the SE debris avalanche, as the volcano had time to fill completely the avalanche scar before the caldera formation.

The intra-caldera cone of Gede has a relative elevation of only $200 \mathrm{~m}$ above the flat floor of a half circular moat depression (named "Alun-Alun") that separates it from the caldera wall lying toward the SSE. The center of the cone is notably shifted to the $\mathrm{N}$ with respect to the caldera center. The internal structure of the cone is well-exposed in a 150-m-high vertical crater wall. The cone is composed of 5 thick (20-50 m) massive lava flows of basaltic andesites (some with rough columnar joints) of unknown age (tentatively we attribute them to Late Pleistocene) (Supplementary Fig. 2a). The lava cone is mantled by a $30-50 \mathrm{~m}$ sequence of pyroclasts probably erupted during formation of the summit crater and the ensuing explosive activity (Supplementary Fig. 2b). We tentatively attribute the formation of the summit crater to the eruption of the Black Pyroclastic Flow (PF) ca. 10,000 yr BP (see Stratigraphy of the North-Eastern volcaniclastic fan). The NNE wall of the summit crater is notably lower than the others and has two breaches, separated by the wall relic named "Rock Sela" (Fig. 1).

The summit crater (Fig. 1b) is partly filled with a small andesitic lava dome that is the source of a $1.5 \mathrm{~km}$-long thick blocky lava flow, which has well-developed marginal levees. The flow descends through the largest (Northern) crater breach onto northern slope of the volcano. Its 30-m-thick flow front rests at elevation of $2300 \mathrm{~m}$. There are two references attributing this lava either to the 1747-1748 eruption (Siebert et al., 2010), or to the 1840 eruption (Petroeschevsky and Klompe, 1951). A very accurate and detailed painting ca. 1850 by Franz Junghuhn (1856) shows this lava flow as very fresh and not vegetated (Supplementary Fig. 3). Thus, following Petroeschevsky 
and Klompe (1951), we attribute this lava to the 1840 eruption. This age is also confirmed by ${ }^{14} \mathrm{C}$ dating of paleosoil on top of the lava (see Stratigraphy of the intra-crater area).

Three explosive funnels (Kawah Ratu $300 \mathrm{~m}$ in diameter, Kawah Lanang $230 \times 170 \mathrm{~m}$, and Kawah Baru $150 \mathrm{~m}$ in diameter) surrounded by aprons of coarse explosive ejecta are located on top of the lava dome (Fig. 1b). They were formed by multiple post-1840 explosive eruptions. Transient shallow-water acid lake and persistent solfataras are located in the largest explosive funnel Kawa Ratu excavated in hydrothemally-altered rocks of the dome.

\section{Holocene stratigraphy}

Substantial volumes of volcaniclastic deposits of Holocene age were found only in narrow NNE sectors on middle-lower slopes of the volcano which we informally refer to as "North-Eastern (NE) volcaniclastic fan" (Fig. 2b). Small volumes of Holocene pyroclasts were found also in the summit area (on the crater rim, in Alun-Alun moat, and around the intra-crater explosive funnels) and on the adjacent southern slope of Pangrango Volcano. On the geological map of Gede, a short tongue of Holocene deposits is shown as also spreading from the volcano summit toward the SW (Situmorang and Hadisantono, 1992). We had no opportunity to investigate stratigraphy of these deposits. Distal ash fall deposits were investigated in the sediments of two small lakes: Danau Situ Gunung and Telaga Warna (Fig. 2a).

\subsection{Stratigraphy of the North-Eastern volcaniclastic fan}

The fan is composed of diverse flowage deposits: pyroclastic flows (PFs), lahars and a small debris avalanche (Figs. 2b and 3). The prevailing $\mathrm{NE}$ distribution of these deposits was determined by the horseshoe topographies of both the summit caldera and the crater that open toward the north. The area of the fan is heavily forested on the upper slopes and densely populated on the lower slopes, thus the deposits are exposed mostly in quarries and few natural outcrops. Areal distribution and volumes of depositional units of the fan are estimated approximately, and indicated only for the most significant deposits. Due to continuing intensive mining, the described outcrops might not exist in the future.

The fan can be subdivided into four regions comprising different stratigraphies and ages of the deposits (from old to young): (A) Cipendawa; (B) Ciwalen; (C) Southern Ciwalen; (D) Cibodas (Fig. 2b). The names are taken from the geologic map of the volcano (Situmorang and Hadisantono, 1992). In each region, the stratigraphic relationships of the deposits were observed in outcrops, while the stratigraphic correlations between the regions were established on the basis of ${ }^{14} \mathrm{C}$ ages.

The Cipendawa region ( $\mathrm{A}$ in Fig. $2 \mathrm{~b}$ ) is situated along Ciherang, Ciguntur and Cipendawa ravines at elevations of 1100-1400 masl. Stratigraphy here is represented by three main pyroclastic flow (PF) units and two lahar units.

The Black PF (informal name) is the oldest Holocene deposit of the $\mathrm{NE}$ fan. In the Ciherang ravine at an elevation of 1180 masl this pyroclastic flow deposit rests on thick paleosoil and fills a deep paleovalley excavated in a strongly weathered sequence of deposits of ancient lahars and PFs. The uppermost PF of the basal sequence contains charcoal older than $43,500 \mathrm{BP}$ - beyond the limit of ${ }^{14} \mathrm{C}$ dating (location \#130 at Figs. 2, 3). The Black PF itself contains charcoal that provided a calibrated ${ }^{14}$ C age of 10,230-9900 yr BP (location \#119 at Figs. 2, 3 and 4a, Table 1). The maximum thickness of the deposit exceeds $25 \mathrm{~m}$; in the deepest quarries its base is not yet exposed. The deposit is dark-gray to black, massive, but locally consists of up to four flow subunits marked by horizontal zones of largest (up to $1 \mathrm{~m}$ ) juvenile rock fragments concentrated in the upper parts of the subunits. The flow subunits were deposited in rapid succession and form a single cooling unit with an oxidized reddish zone $\sim 2 \mathrm{~m}$ thick on top of the uppermost flow subunit.
Vertical degassing pipes (fossil fumaroles) are common throughout the flow thickness.

The Black PF is composed dominantly of fresh juvenile, moderately vesicular dark gray to black scoriaceous basaltic andesite. Vesicles in the scoria are irregular $10-50 \mu \mathrm{m}$, up to $200 \mu \mathrm{m}$ across separated by walls 5-50 $\mu \mathrm{m}$ thick; most vesicles are interconnected (Fig. 5). Non-juvenile rock clasts are rare in the flow. Clastic material of the PF is represented by poorly sorted ash and lapilli with a small fraction of fine ash; scoriaceous bombs up to $0.5 \mathrm{~m}$ are common. Grain-size histograms are bimodal with modes at $>16 \mathrm{~mm}$ and $0.125-1 \mathrm{~mm}$ (Fig. 5).

The Black PF traveled a minimum of $8 \mathrm{~km}$ from the crater; its volume can be approximately estimated to be $0.1 \mathrm{~km}^{3}$. The sedimentological characteristics of the deposit indicate that it was the result of an incandescent, relatively gas-rich and highly concentrated (valleychannelized) PF formed by major explosive magmatic eruption with Volcanic Explosivity Index (VEI) of 3-4 (Newhall and Self, 1982). Because the next older units of Gede Volcano (based on stratigraphy and geomorphic evidence) are beyond the ${ }^{14} \mathrm{C}$ dating limit of 43,500 years (see Table 1 ), we infer that the Black PF was probably erupted after a long period of dormancy or absence of notable explosive activity of the volcano.

In the Ciguntur ravine at an elevation of 1250 masl the Black PF is covered by a massive and slightly indurated lahar deposit up to $20 \mathrm{~m}$ thick. An uncharred wood fragment in the deposit gave a calibrated ${ }^{14} \mathrm{C}$ age of $7790-7600 \mathrm{yr}$ BP (location \#383 at Figs. 2, 3, Table 1 ). We do not know if this lahar was associated with any eruption, or if it was rain-induced event that redeposited the older pyroclastic material.

In the Cipendawa ravine at elevation of 1180 masl the Black PF is covered by a $40 \mathrm{~cm}$ thick paleosoil and then by a sequence of two similar PF units (informally called "Banded Scoria PFs"). Each unit is yellowish brown, massive, 4-5 m thick (Fig. $4 \mathrm{~b}$ ) with rare thin degassing pipes. The deposits are poorly sorted. Clastic material in the PFs consists of ash and lapilli with a small fraction of fine ash. Grain-size histograms are bimodal with the modes $8-32 \mathrm{~mm}$ and $0.25-0.5 \mathrm{~mm}$ (Fig. 5). Rare largest clasts up to $1 \mathrm{~m}$ across are randomly dispersed throughout the thickness of the flows.

Juvenile rock fragments up to $40 \mathrm{~cm}$ in diameter are represented by black scoriaceous basaltic andesite mingled with light gray pumiceous andesite. Vesicles in black scoriaceous basaltic andesite are mostly interconnected, of irregular shape and size (10-100 $\mu \mathrm{m}$, few up to $200 \mu \mathrm{m}$ across) separated by walls $10-50 \mu \mathrm{m}$ thick (Fig. 5). Light gray pumiceous andesite contains vesicles of more uniform sizes, averaging $50 \mu \mathrm{m}$ and separated by very thin walls (few $\mu \mathrm{m}$ thick). Both PFs contain a significant proportion of non-juvenile heterolithologic rock fragments (mostly dense lava clasts).

The lower of the Banded Scoria PFs contains large trunks of partly charred wood that provided a calibrated ${ }^{14} \mathrm{C}$ age of $4050-3990 \mathrm{yr} \mathrm{BP}$, and the upper PF contains fragments of completely charred wood that provided a calibrated ${ }^{14} \mathrm{C}$ age of $4090-3910 \mathrm{yr}$ BP (location \#97 at Figs. 2, 3, Table 1). Because of the overlapping ages and because they are separated by only thin lenses of reworked material, we believe that the two Banded Scoria PF units were deposited within short time interval.

The Banded Scoria PFs traveled a minimum $8 \mathrm{~km}$ from the crater; their combined volume can be approximately estimated to be $0.03 \mathrm{~km}^{3}$. Characteristics of the deposits indicate that they were left by highly concentrated (valley-channelized) gas-poor PFs. The lower PF was moderately hot (contains partly charred wood), and the upper PF was incandescent (contains completely charred wood). Both were formed by mild explosive eruption (or two eruptions closely spaced in time), possibly phreatomagmatic (with VEI about 2-3). We suggest possible phreatomagmatic character of these eruptions because of high proportion of heterolithologic non-juvenile rock fragments and low average vesicularity of the juvenile clasts; more arguments are provided in the Discussion section.

The PFs are overlain by a lahar deposit up to $5 \mathrm{~m}$ thick containing uncharred wood fragments (Fig. 4b). We do not know if this lahar was 
associated with any eruption, or it was rain-induced event that redeposited the older pyroclastic material.

The Ciwalen region (B in Fig. 2b) is located along Cikundul, Ciawital and Ciwalen rivers at elevations of 800-900 masl. The stratigraphy here has four similar PF units (informally called "Lithic-rich PFs"). There are no signs of notable depositional gaps between the flow units.

The Lithic-rich PF deposits are gray to brown-gray, massive, locally weakly to moderately indurated with few degassing pipes; each unit is 3-7 m thick (in the Cikundul Valley one of the flows is more than $20 \mathrm{~m}$ thick). The PFs are composed of very poorly sorted ash and lapilli with rare bombs up to $1 \mathrm{~m}$ across (Fig. 4c). Grain-size histograms either have no prominent modes, or one coarse mode $>16 \mathrm{~mm}$ (Fig. 5). Fragments of juvenile material are represented by dark gray-black poorly to moderately vesicular scoriaceous basaltic andesite, a few are mingled with small volumes of light gray pumiceous andesite and dacite (much less frequent than in the Banded Scoria PFs). Bomb-size juvenile clasts (up to $0.5 \mathrm{~m}$ ) frequently have chilled cauliflower outer surfaces. Vesicles in the scoriaceous material are interconnected, of irregular shape 10-100 $\mu \mathrm{m}$ across separated by walls $10-30 \mu \mathrm{m}$ thick (Fig. 5). All PFs contain significant proportion of non-juvenile heterolithologic, mostly dense angular lava clasts. The lowermost PF also contains a significant fraction of well-rounded clasts of vesicular yellowish-white dacite pumice $1-5 \mathrm{~cm}$ in diameter. The pumice was picked up by the flow either from a deposit of older eruption, or more probably from the deposit of earlier stage of the same eruption (see the description of the deposit on the southern slope of Pangrango below). The Lithic-rich PFs contain abundant charred and partly charred fragments of wood, and in many cases large partly charred buried standing trees up to $2 \mathrm{~m}$ in diameter that were dated as ca. $1200 \mathrm{yr}$ BP (locations BD and \#95 at Figs. 2, 3, Table 1).

The Lithic-rich PFs traveled at least $12 \mathrm{~km}$ from the crater and have a combined estimated volume of approximately $0.15 \mathrm{~km}^{3}$. The large proportion of non-juvenile clasts and presence of only partly charred wood fragments make some units notably similar to hot lahar deposits. However, several tests of vector of remnant magnetization of the constituent rock clasts done in the field (using a hand-held magnetometer) have shown uniform orientation indicating that depositional temperatures of the flows were at least several hundred degrees Centigrade. The characteristics of the deposits indicate that they were left by moderately hot gas-poor highly concentrated (valley-channelized) PFs formed by explosive, probably phreatomagmatic eruptions with VEI about 3. We suggest phreatomagmatic character of these eruptions because their products had low depositional temperatures, high proportion of non-juvenile rock fragments, and low average vesicularity of the juvenile clasts that commonly have chilled outer surfaces; more arguments are provided in the Discussion section.

The Southern Ciwalen region ( $\mathrm{C}$ in Fig. $2 \mathrm{~b}$ ) is a small branch of the NE volcaniclastic fan that was deposited along the Cipendawa River flowing through a narrow notch in transverse ridge Gunung Kasir composed of basement rocks. The deposits of the branch are found only in the lower part of the Cipendawa Valley (downstream from the notch); probably they were stripped out of the upstream areas by erosion. The region is adjacent to the Ciwalen area, but its stratigraphy is different. At 850 masl the stratigraphy has 2 units (Fig. 3). The lower unit (informally called the "Black Lahar") is $5 \mathrm{~m}$ thick, massive, clast supported, poorly sorted sandy gravel composed of relatively monolithologic dark gray to black angular fragments of dense lava. Grain-size histograms have no prominent modes. The deposit buried small uncharred standing trees that provided a calibrated ${ }^{14} \mathrm{C}$ age of $1280-950 \mathrm{yr}$ BP (location \#100 at Fig. 2, Table 1).

Characteristics of the deposit indicate that it was left by a cold, highly concentrated lahar. Material of the deposit could originate from outward collapse of part of the crater wall (when the NE crater breach was formed). This part of the crater wall was located in the headwaters

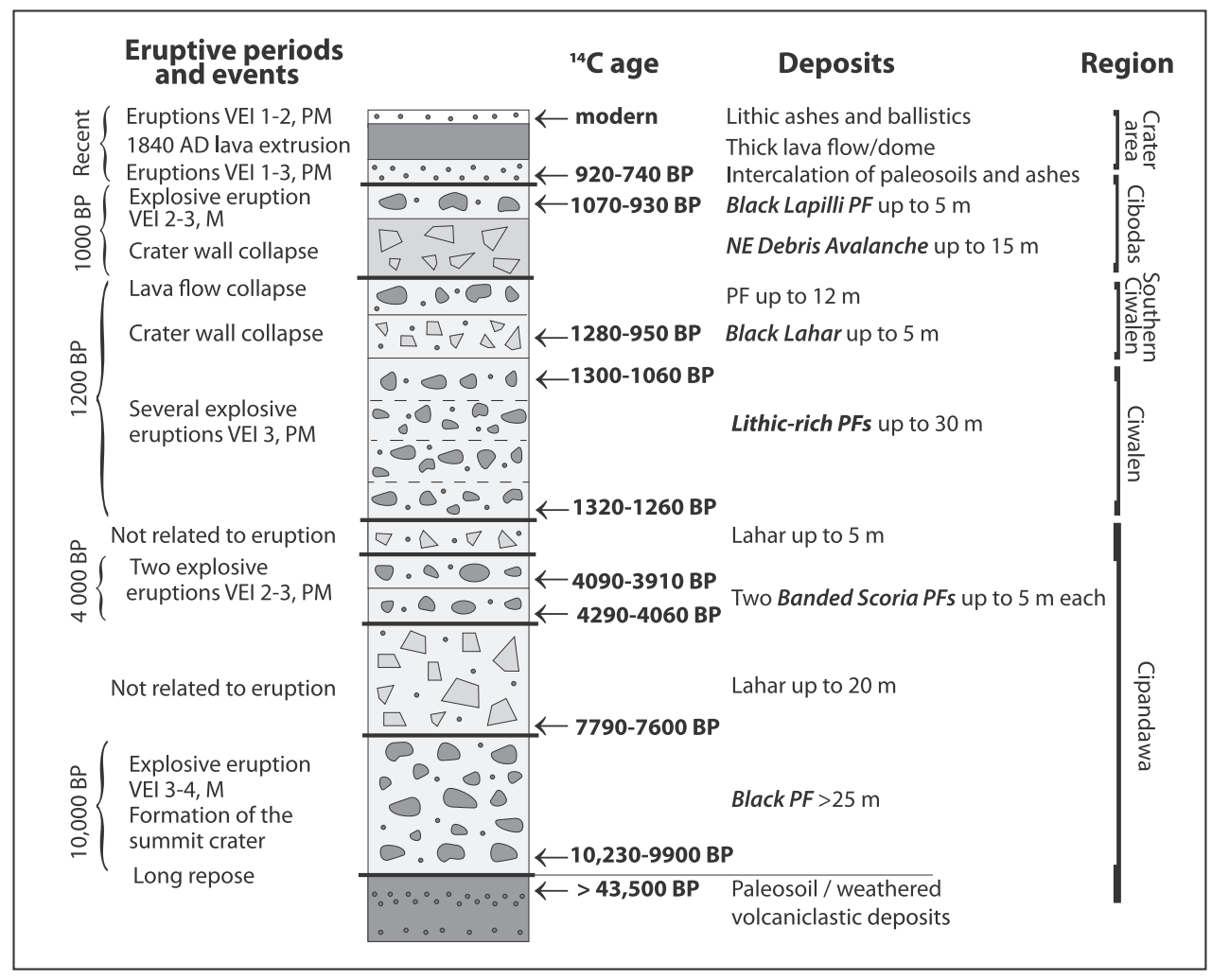

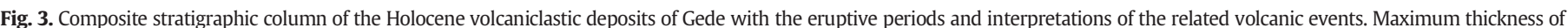

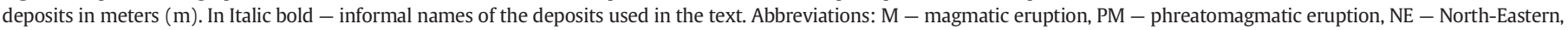

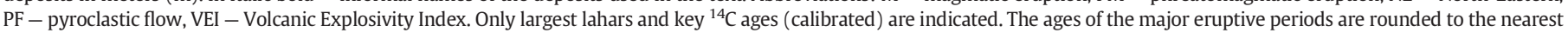
thousand. 
a

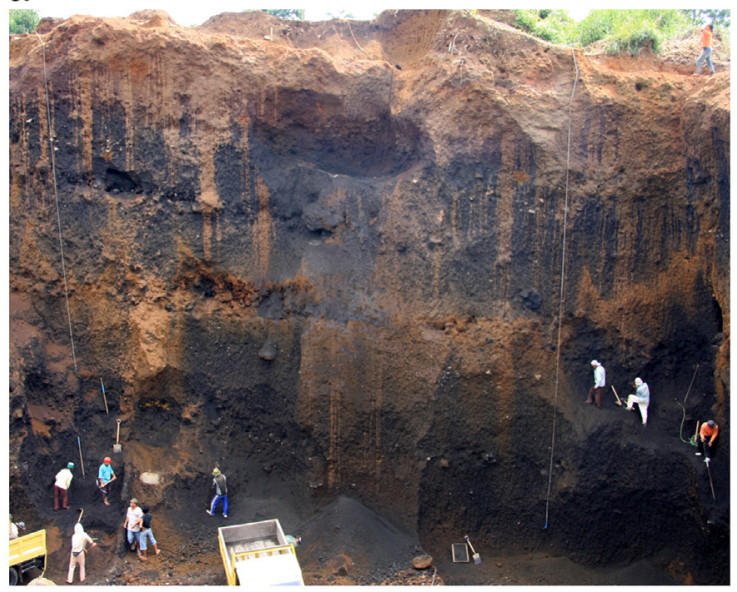

C

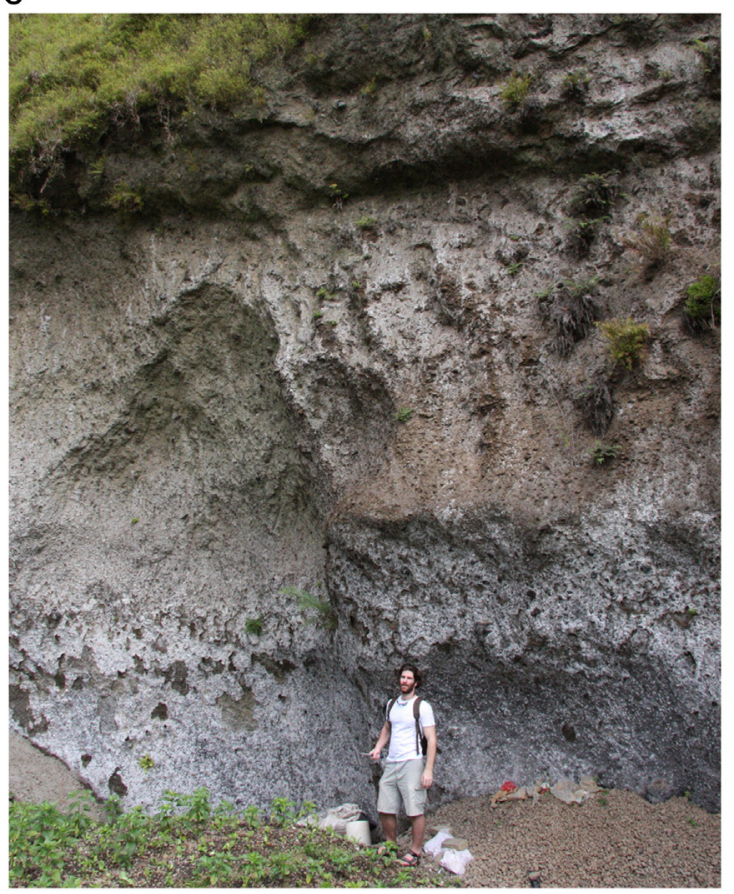

$\mathrm{b}$

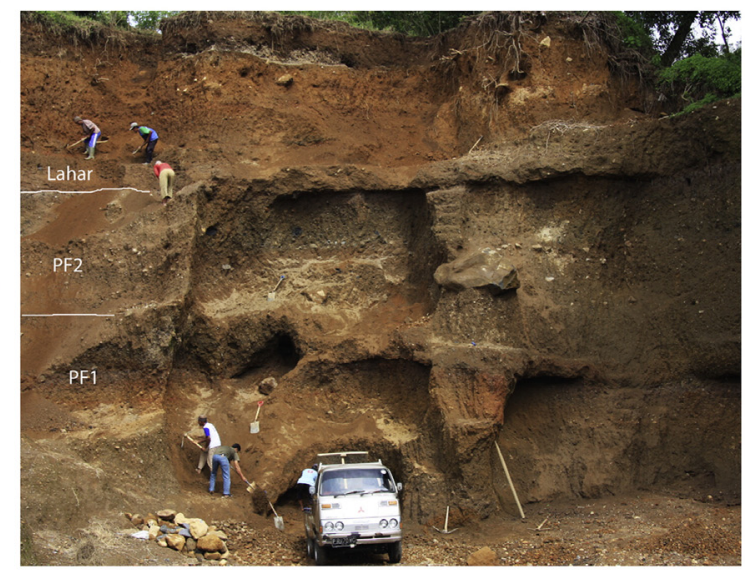

d

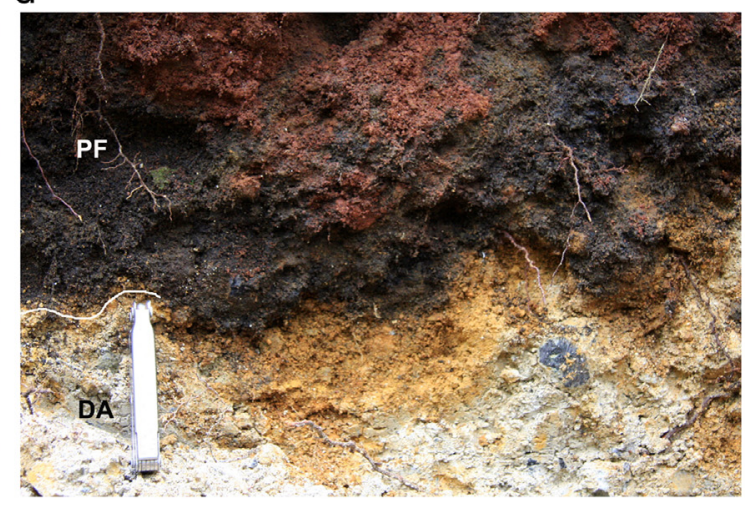

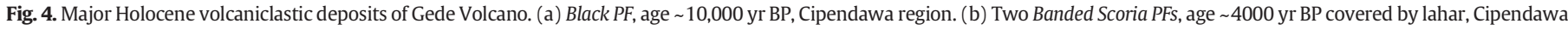

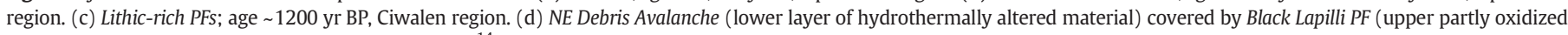
layer); age $\sim 1000$ yr BP, Cibodas region. The calibrated ${ }^{14} \mathrm{C}$ ages are rounded to the nearest thousand (see Fig. 3). Photos by A. Belousov.

of the Cipendawa River, and was composed of similar material (massive dark gray lava flows).

The Black Lahar deposit is directly overlain (without signs of the depositional gap) by a massive PF up to $12 \mathrm{~m}$ thick (Fig. 3 and Supplementary Fig. 4a). It is composed of subrounded blocks of gray dense andesite up to $0.5 \mathrm{~m}$ across suspended in a light gray poorly-sorted and moderately-indurated fine-grained matrix that has multiple welldeveloped degassing pipes. The andesite blocks have radial prismatic cooling joints. Characteristics of the unit indicate that it was deposited by hot and highly concentrated (valley-channelized) block-and-ash PF. The material possibly originated from collapse of a moving hot lava flow that within short time interval followed the crater wall collapse, which deposited the Black Lahar; more arguments are provided in the Discussion section.

The calibrated ${ }^{14} \mathrm{C}$ ages of the Black Lahar and the PF units (1280$950 \mathrm{yr} \mathrm{BP}$ ) are similar (or possibly somewhat younger) to the ages of the Lithic-rich PFs in Ciwalen (ca. 1200 yr BP, Table 1). Thus, we attribute them to the same eruption period (probably the Black Lahar and the overlying PF were deposited during the final part of the period).

The Cibodas region ( $\mathrm{D}$ in Fig. $2 \mathrm{~b}$ ) lies along the Ciwalen River at elevations of 1150-2450 masl. At low elevations the area (including the famous Cibodas Botanical Garden) is characterized by gentle hummocky topography with scattered clusters of angular blocks and individual large (up to $5 \mathrm{~m}$ across) dense blocks of gray lava (Supplementary Fig. 4b). Outcrops of the internal part of the deposit show very poorly sorted, coarse-grained, massive, clast supported breccia composed of the same angular fragments of dense lava mixed with hydrothermally altered and oxidized rock clasts. On higher elevations (Pasirciguntur area), the deposit is composed mostly of highly hydrothermally altered (some up to condition of soft clay) yellow and white rocks.

The characteristics of the unit indicate that it was deposited by cold and relatively dry debris avalanche (informally called "NE Debris Avalanche") originated from small gravitational collapse of the volcanic 

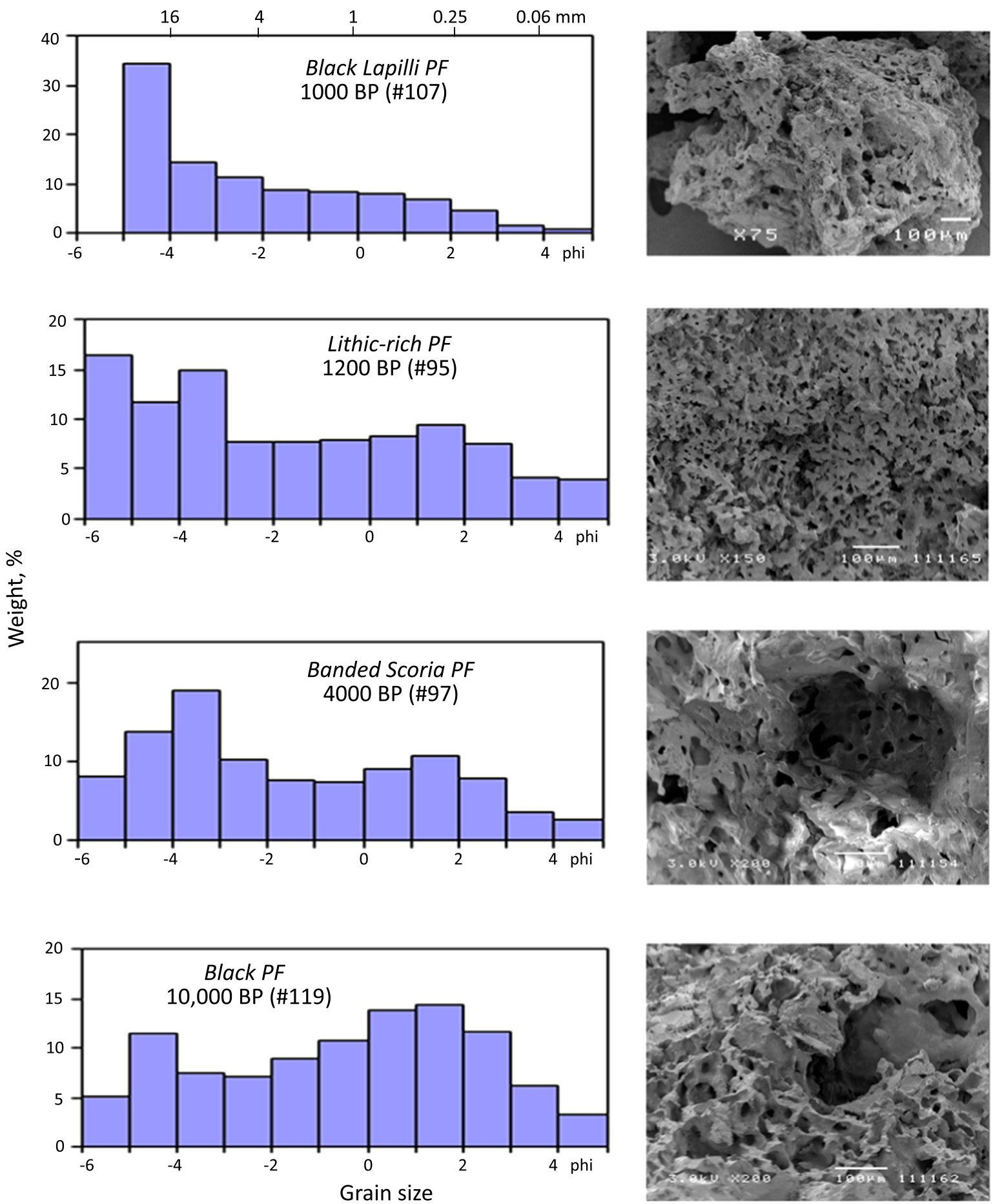

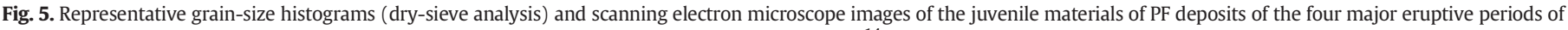
Gede Volcano in the Holocene. Ages and location numbers (in brackets) are indicated. The calibrated ${ }^{14} \mathrm{C}$ ages are rounded to the nearest thousand (see Fig. 3 ).

edifice. We suggest that this could be the outward collapse of part of the crater wall (when the Northern crater breach was formed). This part of the crater wall was located in the headwaters of the Ciwalen River, and was composed of similar dense lava flows locally weakened by hydrothermal alteration (a strong solfatara still exists in the breach area).

The avalanche traveled approximately $9 \mathrm{~km}$ from the crater. The thickness of the deposit is estimated to be 3-5 m over an area of $10 \mathrm{~km}^{2}$, with a volume of $0.03 \mathrm{~km}^{3}$. The hummocky surface of the deposit is covered by a $1.5 \mathrm{~m}$-thick sequence of intercalating layers of paleosoil and layers of fine-grained ash deposits. The layer of paleosoil directly above the avalanche deposit and below the lowermost distinctive layer of light gray ash provided a calibrated ${ }^{14} \mathrm{C}$ age of $920-740 \mathrm{yr}$ BP (location \#127 at Figs. 2, 3, Table 1).

At elevations higher than 2300 masl (Pasirciguntur area), the NE Debris Avalanche deposit is directly overlain by a black to dark gray friable layer, 1-3 m thick, composed of lapilli and scoriaceous bombs up to $0.4 \mathrm{~m}$ in diameter (Fig. $4 \mathrm{~d}$ and Supplementary Fig. 4c). The upper part of the layer has a reddish oxidation zone indicating high depositional temperature. The deposit (informally called "Black Lapilli $P F$ ") is massive, clast supported, moderately sorted and strongly depleted 
in fine-grained material. Grain-size histograms have a prominent coarse mode at $>16 \mathrm{~mm}$ (Fig. 5). Most of the clasts are composed of juvenile black to dark gray moderately vesicular basaltic andesite to andesite. Irregular shaped (10-100 $\mu \mathrm{m}$ across) vesicles are interconnected and separated by 5-30 $\mu \mathrm{m}$ thick walls (Fig. 5). Sparse non-juvenile clasts consist of gray fragments of dense lava. Locally, the deposit contains fragments of charred wood that gave a calibrated ${ }^{14} \mathrm{C}$ age of $1070-930 \mathrm{yr}$ BP (location \#107 at Figs. 2, 3, Table 1). The Black Lapilli PF unit covers area of approximately $3 \mathrm{~km}^{2}$ and its volume is approximately estimated to be $0.01 \mathrm{~km}^{3}$. The deposit is partly covered (the contact was not observed) by a historic (1840 AD) lava that flowed out of the Northern crater breach (see Stratigraphy of the intra-crater area).

The characteristics of the Black Lapilli PF indicate that it was deposited by relatively small incandescent avalanches of lapilli and bombs erupted by a moderately explosive, magmatic eruption of VEI about 2-3. We suggest that this eruption triggered the collapse of the northern crater wall, which formed the NE Debris Avalanche.

\subsection{Stratigraphy of the summit area}

\subsubsection{The Crater rim pyroclastic sequence}

A complete section of the pyroclasts deposited in the summit area is exposed only along steep inner cliff of the crater rim of Gede. Most parts of the section are not accessible and were observed only from a distance. The deposit has a total thickness of approximately $50 \mathrm{~m}$ and rests on the uppermost thick lava flow exposed in the crater wall (Supplementary Fig. 2b).

The lower 20-30 m part of the sequence is strongly indurated (probably agglutinated) and forms a vertical cliff composed of 3-5 well-defined parallel layers (each 5-10 m thick). The layers are pink to reddish-gray indicating various degrees of oxidation due to high depositional temperatures. The material consists of well-sorted coarse lapilli, bombs, and few large angular lithic blocks (up to $3 \mathrm{~m}$ across). Subtle horizontal parallel fabric is visible in some layers. The deposits probably represent proximal pyroclastic fallout of several pulses of a strong VEI 4 magmatic eruption of sub-Plinian type.

The middle $10 \mathrm{~m}$ part of the sequence is moderately indurated and forms an $80^{\circ}$ slope composed of multiple gray-brown-gray vaguely defined undulating layers that are decimeters to a few meters thick. The layers are composed of poorly sorted lapilli containing multiple angular lithic blocks.

The upper $15 \mathrm{~m}$ part of the sequence is lithologically similar to the middle part but is weakly indurated to friable and forms a $30-45^{\circ}$ slope. The uppermost unit accessible from the crater rim is composed of decimeter-to meter thick layers with diffuse contacts. These layers are composed of poorly sorted lapilli with black moderately-vesicular juvenile and non-juvenile angular rock fragments with various degrees of hydrothermal alteration. The percentage of juvenile lapilli strongly fluctuates from layer to layer. Layers also contain large ballistic angular blocks and rare bread-crust bombs of gray andesite up to $0.5 \mathrm{~m}$ across. In the sequence there are several intercalated thin layers of fine ash containing accretionary lapilli. Based on these characteristics, the deposits of the middle and upper parts of the crater rim sequence are interpreted as proximal pyroclastic fallout of multiple weak to moderate VEI 2-3 phreatomagmatic eruptions of Vulcanian type in a broad sense.

We have no data about ages of the crater rim pyroclastic sequence. Based on characteristics of the deposit we tentatively attribute its lower agglutinated part to the $10,000 \mathrm{yr}$ BP eruption that deposited the Black PF of the NE fan; it was the strongest magmatic explosive eruption of Gede Volcano in Holocene. Possibly that eruption formed (or enlarged) the summit crater. The middle moderately indurated part of the sequence probably corresponds to several eruptions that deposited multiple PFs of the NE fan with ages of 4000-1200 yr BP. The upper friable part of the sequence probably corresponds to the $1000 \mathrm{yr}$ BP and multiple younger eruptions.

\subsubsection{The Alun-Alun moat}

The Alun-Alun moat is a flat grassy plain at the elevation of $\sim 2750$ masl providing good conditions for preservation of fallout pyroclasts. The area has no natural outcrops; we excavated a shallow pit (location \#113 at Fig. 2, Supplementary Fig. 4d) and observed (from bottom to top): fine to medium-grained poorly sorted lapilli ( similar to the uppermost layers exposed on the crater rim) $>5 \mathrm{~cm}$; $3 \mathrm{~cm}$ of paleosoil (calibrated age 340-290 yr BP, Table 1); a sequence of intercalated gray and light gray poorly sorted ash layers $30 \mathrm{~cm}$ thick (some layers contain accretionary lapilli); and $7 \mathrm{~cm}$ of poorly developed sandy soil of modern age. All the ash layers exposed in the pit are composed of blocky poorly vesicular particles of andesitic composition; some particles are hydrothermally altered.

The ground surface of the Alun-Alun moat is pocked with large ballistics and corresponding impact sags (up to $5 \mathrm{~m}$ in diameter). Most of the ballistics are angular non-juvenile blocks of dense rocks (up to $1.5 \mathrm{~m}$ in diameter) similar to material of the intra-crater lava dome/flow (see Stratigraphy of the intra-crater area). A few ballistics are andesitic bread-crust bombs (up to $1 \mathrm{~m}$ in diameter) - juvenile material of the eruptions.

Characteristics of the ash deposits indicate that they represent fallout products of multiple relatively weak phreatomagmatic eruptions of the historical period, which are akin to Vulcanian type in a broad sense. We infer that the ballistics were ejected by the strongest explosions of the historical eruptions.

\subsection{Stratigraphy of the intra-crater area}

On top of the intra-crater lava dome, around the Kawa Ratu explosive funnel, there is an apron of explosive ejecta deposits up to 5-7 m thick. The complete section of the apron is exposed along steep inner slope of the crater. The apron has crude undulating layering vaguely defined by varying concentration of the largest rock clasts (up to $2 \mathrm{~m}$ across); the layer contacts are diffuse. The layers are brown-gray and composed of poorly sorted coarse lapilli and bombs in ash matrix. Diverse angular fragments of mostly dense non-juvenile rocks that are hydrothermally altered to various degrees dominate in the deposit. There are also very rare bread crust bombs of gray juvenile andesite. The material of the pyroclastic apron obviously represents proximal deposits of the post-1840 weak phreatomagmatic eruptions (Vulcanian in a broad sense).

About $600 \mathrm{~m}$ to the $\mathrm{N}$ from the explosive funnel, the thickness of the apron deposit declines to $<0.5 \mathrm{~m}$. In a small excavation pit on the surface of the intra-crater lava flow (location \#143 at Fig. 2) we observed (from bottom to top): $15 \mathrm{~cm}$ of poorly sorted olive brown lapilli ash; $8 \mathrm{~cm}$ of paleosoil; $20 \mathrm{~cm}$ of intercalated thin medium to fine-grained ash layers with thin layers of paleosoils; $10 \mathrm{~cm}$ of poorly developed modern soil and duff. The ash deposits are composed of blocky poorly vesicular particles; most of the particles are hydrothermally altered. ${ }^{14} \mathrm{C}$ dating of the lowermost paleosoil provided a modern age (Table 1 ). This dating confirms the $1840 \mathrm{AD}$ age of the underlying lava flow. The lowermost ash layer in the pit we interpret as deposit of eruptions in the period 1840-1909, and the uppermost sequence of ashes as deposits of the 1947-1957 eruptions (Supplementary Fig. 1).

\subsubsection{The southern slope of Pangrango}

The southern slope of Pangrango (located less than $3 \mathrm{~km}$ from the crater of Gede) is mantled by a sequence of diverse layers of pyroclasts more than $2 \mathrm{~m}$ thick. The most prominent upper layer is $0.5-1 \mathrm{~m}$ thick and composed of poorly sorted fine to medium-grained white ash (Supplementary Fig. 4e). The upper part of the layer contains pumice lumps of dacitic composition up to $8 \mathrm{~cm}$ across. There are two varieties of pumice: white (abundant) and gray (few). The deposit contains multiple fragments of charcoal that provided a calibrated ${ }^{14} \mathrm{C}$ age of 1270-1080 yr BP (location \#141 at Fig. 2, Table 1). 
The pumice is highly vesicular. The bubbles are commonly $10-50 \mu \mathrm{m}$, and some $>500 \mu \mathrm{m}$ in diameter with thin $<1 \mu \mathrm{m}$ interbubble walls. The white pumice has mostly isolated bubbles, in some samples the bubbles are strongly elongated (pipe-like). The gray pumice has mostly interconnected spherical bubbles with multiple thin filaments of glass connecting opposite bubble walls.

The characteristics of the deposit indicate that it was left by strongly inflated incandescent pyroclastic density current (PDC) emplaced during a highly explosive Plinian eruption with VEI of about 3-4. There is uncertainty about the source of this deposit. It rests on the slope of Pangrango and contains pumice that is atypical for eruptive products of Gede. Compositionally similar highly vesicular pumice was found on the NE slope of Gede in the lowermost of the Lithic-rich PFs of the Ciwalen area (where the pumice is interpreted as picked-up non-juvenile material). Ages of the Lithic-rich PFs and the pumice-bearing PDC are similar. Thus, either the pumice-bearing PDC was erupted by a recent eruption of Pangrango that, in this case, should be considered as active volcano. Or, more probably, in the beginning of the $1200 \mathrm{yr}$ BP eruption of Gede there was a highly explosive Plinian phase rather unusual for the volcano.

\subsection{Distal ashes}

Preservation potential of thin layers of fine-grained distal ash fall deposits in tropical soils is poor. To determine ages and estimate frequency of distal ash falls around Gede, we undertook coring of bottom sediments of two small lakes located on lower slopes of the volcano: Danau Situ Gunung and Telaga Warna (Fig. 2).

Danau Situ Gunung is a maar of unknown age located on the boundary between merging slopes of Pangrango and Gede, $8 \mathrm{~km} \mathrm{SW}$ from the summit crater of Gede (Fig. 2a). The maar lake is less than $1 \mathrm{~m}$ deep. The retrieved $60 \mathrm{~cm}$ core of bottom deposits consists of (from bottom to top): dense dark-brown peat $>45 \mathrm{~cm}$ thick covered by $15 \mathrm{~cm}$ of semi fluid fine-grained dark gray organic sediment. The sedimentation in the original maar lake was completed a long time ago by accumulation of the peat, and the gray organic sediment has a modern age. Thus the currently existing lake is manmade (there is small dam on the stream draining the lake). No ash layers were found in the core.

Telaga Warna is located $10 \mathrm{~km}$ NNE from Gede in a head scarp of a small non-volcanic landslide (Fig. 2). The lake is $7 \mathrm{~m}$ deep. The retrieved $2 \mathrm{~m}$ long core (the base of the sediment was not reached) was composed of fine-grained greenish dark-gray organic sediment containing abundant partly decayed remnants of water plants. In the core there were two thin ash layers at depths of about 120 and $150 \mathrm{~cm}$ from the lake bottom (depths are approximately determined). The upper layer is $2 \mathrm{~mm}$ thick fine-medium grained ash composed of small fragments of white pumice and glass shards. Organic sediment below the ash layer provided a calibrated ${ }^{14} \mathrm{C}$ age of $480-300 \mathrm{yr}$ BP (Table 1). The lower layer is $5 \mathrm{~mm}$-thick medium-grained ash. It is composed of gray, poorly vesicular rock fragments with blocky morphology and admixture of light-gray subrounded fragments of hydrothermally altered rocks. Organic sediment below the ash layer provided a calibrated ${ }^{14} \mathrm{C}$ age of $530-500 \mathrm{yr}$ BP (Table 1).

Strong weathering of the ash particles does not allow determining their source volcanoes basing on chemical compositions. The pumice ash probably does not belong to Gede, because we did not find the corresponding proximal pumice fallout deposit of similar age on the volcano. The lithic ash probably belongs to Gede, because eruptions of such ashes were common for Gede during last several hundred years of the volcano history. Thus, investigation of the bottom sediments of the Telaga Warna shows that Gede produced few distal ash falls during last 500 years in the NE area of the volcano.

\section{General petrographic and petrological description of Gede eruptive products}

We performed petrographic and petrological investigation (including major and trace element analysis) of the juvenile materials of the different deposits of Gede. The detailed petrological data will be published in separate paper. Below we report the most important aspects relevant to this study.

Juvenile materials of pyroclastic units of Gede are commonly heterogeneous at the macroscopic and microscopic scales (Figs. 6 and 7). Clasts of banded scoria consisting of alternating dark and light bands ranging in thickness between a few $\mathrm{cm}$ and $\mathrm{mm}$ are abundant in the $4000 \mathrm{yr}$ BP and $1200 \mathrm{yr}$ BP PFs. All the juvenile materials have porphyritic textures with phenocrysts of plagioclase and pyroxene being the most abundant. Exceptions are pumices from the $1200 \mathrm{yr}$ BP PDC deposited on the southern slope of Pangrango, and the light bands in banded scoria of the $4000 \mathrm{yr}$ BP PFs and in smaller amount in the $1200 \mathrm{yr}$ BP PFs where the texture is pumiceous with highly vesicular glassy groundmass.

Samples of lava flows (from the crater wall and from the intra-crater lava dome) exhibit seriate textures with dense microlite-rich groundmasses. The most samples are crystal-rich with phenocryst contents between 30 and $40 \mathrm{vol} . \%$. The most abundant phenocrysts are plagioclase, clinopyroxene, and orthopyroxene, Fe-Ti oxides; amphibole and olivine are also present in some samples. Accessorial apatite occurs in the samples of the evolved rocks.

The >43,500 yr BP Gumuruh samples (fragmented lavas from the SE debris avalanche) are compositionally uniform, high-silica basalts with moderate concentration of $\mathrm{Mg}$, and rather high $\mathrm{Al}\left(\mathrm{SiO}_{2}=51.2-\right.$ 51.8 wt.\%; $\mathrm{Al}_{2} \mathrm{O}_{3}=19.4-20.0$ wt.\%; $\mathrm{MgO}=4.3-4.8$ wt.\%) (Fig. 8), e.g., high-alumina basalts typical for subduction zones (Winter, 2001). The samples have a mineral assemblage made of (in order of decreasing abundance) plagioclase, clinopyroxene, olivine, amphibole, and $\mathrm{Fe}-\mathrm{Ti}$ oxides (spinel) (Fig. 7a). Crystals are mostly euhedral except for amphibole, which shows slight resorption on edges; reaction textures and secondary minerals are not observed. Groundmass microlites are overwhelmingly plagioclase and minor clino- and orthopyroxene. There are limited microscopic and compositional evidence in the minerals for open system processes (e.g., magma mixing) in these samples compared to later produces of Gede.

Lavas of the intra-caldera cone of Gede have compositional and mineralogical features very similar to the juvenile material of the $10,000 \mathrm{yr} \mathrm{BP}$ Black PF that we will now describe in detail. The PF contains blocks of basaltic andesites, with fairly uniform silica content, but a large range in $\mathrm{Al}$ and $\mathrm{Mg}\left(\mathrm{SiO}_{2}=55.0-56.4\right.$ wt.\%; $\mathrm{Al}_{2} \mathrm{O}_{3}=18.6-21.5$ wt.\%; $\mathrm{MgO}=2.2-3.9 \mathrm{wt} . \%$ ) (Fig. 8). It have mainly phenocrysts of plagioclase ( 30 vol.\%), clinopyroxene and orthopyroxene (1-6 vol.\%). The matrix contains abundant plagioclase, minor pyroxenes, and accessory olivine (Fig. 7b). Pyroxenes and olivine occasionally form glomerocrysts. Plagioclase phenocrysts typically show a sieve texture in the most of the crystals, but the rims are inclusion free. Both pyroxenes are reversely-zoned suggesting multiple magmatic events (or within reservoir circulation) in their growth history. The sieved plagioclase and the zoned pyroxenes reflect open system processes, mainly replenishment of mafic liquid in a pre-existing more silicic reservoir (e.g., Streck, 2008).

The 4000 yr BP Banded Scoria PFs and the 1200 yr BP Lithic-rich PFs contain juvenile materials that are very similar both mineralogically and petrologically. Therefore we describe them together and emphasize only the main differences. Bulk-rock compositions tend to be more evolved than in older units and range from basaltic andesite to andesite $\left(\mathrm{SiO}_{2}=54.4-61.0\right.$ wt.\%; $\mathrm{Al}_{2} \mathrm{O}_{3}=18.9-17.1$ wt.\%; $\mathrm{MgO}=4.6-2.7$ wt.\%), except of the single clast of crystal-poor, pumiceous rhyodacite found in the 1200 yr BP unit $\left(\mathrm{SiO}_{2}=69.1 \mathrm{wt} . \% ; \mathrm{Al}_{2} \mathrm{O}_{3}=15.8 \mathrm{wt} . \% ; \mathrm{MgO}=\right.$ $1.1 \mathrm{wt} . \%)$. The most mafic samples of each unit have about the same composition, whereas the most evolved compositions show larger 


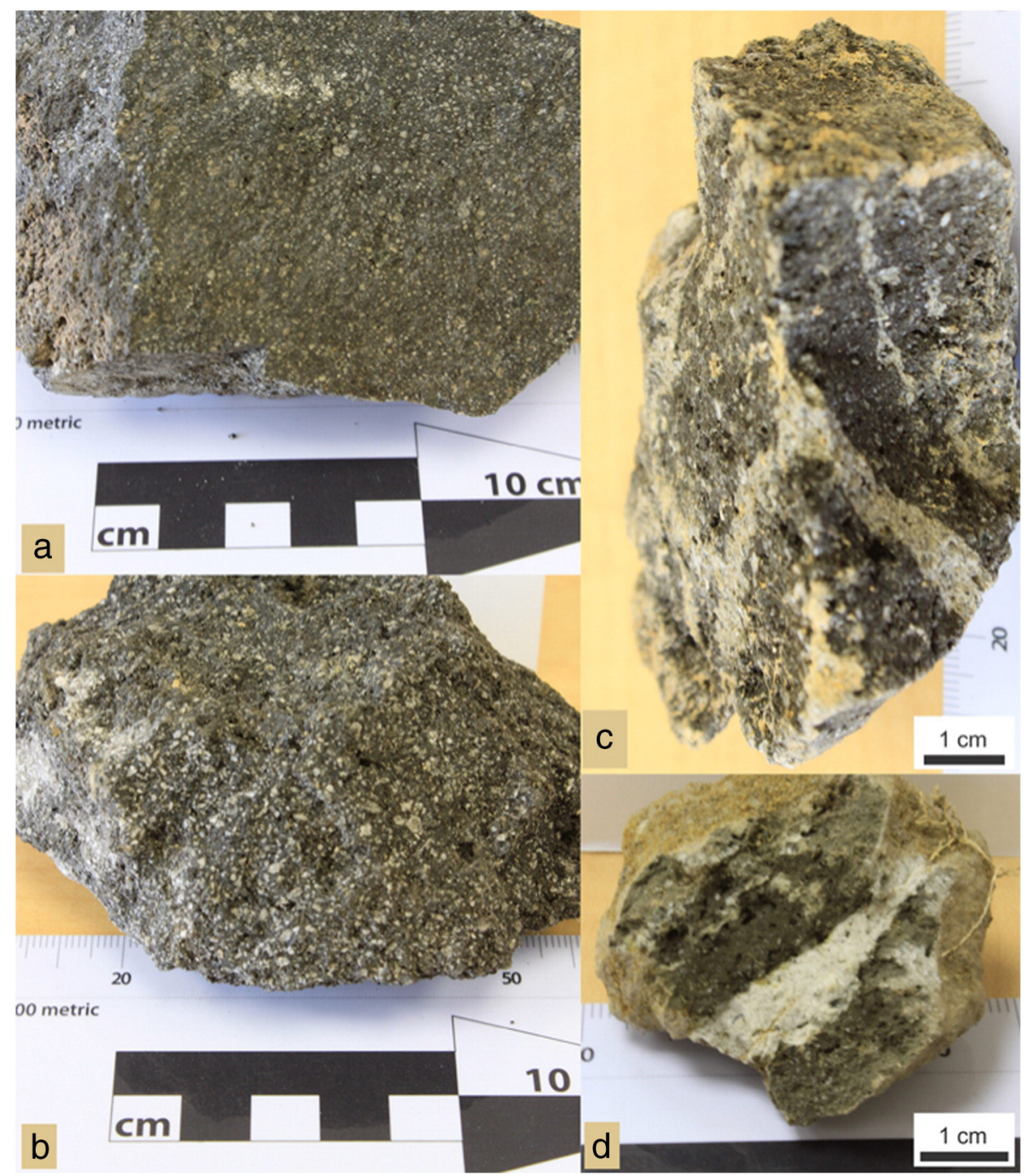

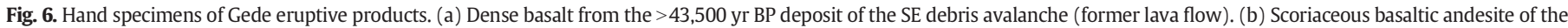

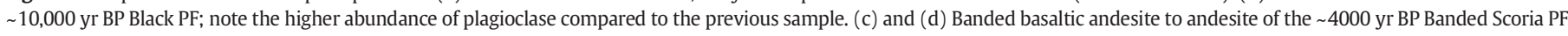

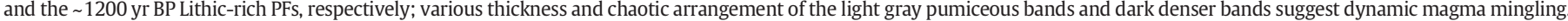
The calibrated ${ }^{14} \mathrm{C}$ ages are rounded to the nearest thousand (see Fig. 3).

variety (Fig. 8). Plagioclase represents the most abundant phenocryst type and there is a wide variety of mafic minerals including ortho-, clinopyroxenes, and amphibole. Anhedral olivine (Fig. 7d) rarely occurs and probably it is of xenocrystic origin given the evidence of coexisting contrasting magmas in the banded scoria samples (Fig. 6). Fe-Ti oxides and apatite are accessory minerals. Groundmasses are microlite-rich; the most abundant microlite phases are plagioclase and subordinate pyroxenes (including pigeonite); accessory olivine and magnetite are also present. The darks bands have a basaltic andesite composition $\left(\mathrm{SiO}_{2}=54-56 \mathrm{wt} . \%\right)$, whereas the light bands are mainly andesites $\left(\mathrm{SiO}_{2}=60-61 \mathrm{wt} . \%\right)$. Both bands have the same phenocryst assemblage of plagioclase, orthopyroxene, clinopyroxene, amphibole, and olivine (Fig. 7c and d). All mafic minerals show pronounced reverse zoning, and olivine has reaction rims indicating the open-system processes and interaction between magmas of contrasting compositions (Fig. 7c). Olivine is rare in the light bands and the reaction textures are much more developed (Fig. 7d). Amphibole in the light bands is almost completely reacted suggesting its instability.

The 1000 yr BP Black Lapilli PF is composed of juvenile material that shows a large compositional and mineralogical range of magmas, ranging from low-silica basaltic andesites $\left(\mathrm{SiO}_{2}=52 \mathrm{wt} . \% ; \mathrm{Al}_{2} \mathrm{O}_{3}=19.5 \mathrm{wt} . \%\right.$; $\mathrm{MgO}=5.0$ wt.\% $)$ to andesites $\left(\mathrm{SiO}_{2}=61.1 \mathrm{wt} . \% ; \mathrm{Al}_{2} \mathrm{O}_{3}=17.1 \mathrm{wt} . \%\right.$;
$\mathrm{MgO}=2.7$ wt.\%) (Fig. 8). The most mafic samples have a mineral assemblage similar to that of the $>43,500$ yr BP Gumuruh rocks: clinopyroxene, plagioclase phenocrysts, olivine microphenocrysts, but amphibole is absent (Fig. 7e). The andesites from this unit show similar mineral assemblages to the $10,000 \mathrm{yr}$ BP. Plagioclase, clinopyroxene and orthopyroxenes are still the most abundant phenocrysts and also tend to show evidence of open-system processes, including sieved plagioclase and complexly zoned pyroxenes.

The $1200 \mathrm{yr} B P$ PDC from the southern slope of Pangrango is composed of silica-rich $\left(\mathrm{SiO}_{2}>65\right.$ wt.\%, Fig. 8) crystal-poor dacite pumice ( $<10$ vol.\% phenocrysts), that is chemically and texturally similar to the dacite pumice found in the $1200 \mathrm{yr}$ BP Lithic-rich PFs. Phenocrysts are plagioclase, clinopyroxene and rare amphibole. The samples show high degrees of weathering, so it is difficult to make reliable inferences about the processes that might be recorded in the minerals.

The 'Recent' group combines products of the youngest eruptive period: the bread crust bombs from the Alun-Alun moat (probably of historic eruptions) and the $1840 A D$ intra-crater lava dome/flow (Fig. 8). These are all andesitic $\left(\mathrm{SiO}_{2}=58.4-60.8\right.$ wt.\%; $\mathrm{Al}_{2} \mathrm{O}_{3}=17.5-17.2$ wt.\%; $\mathrm{MgO}=3.5-2.9$ wt.\%) with the same varied phenocryst mineral assemblage: sieved plagioclase, clinopyroxene, orthopyroxene, amphibole and olivine. Olivine and amphibole show reaction rims (Fig. 7f). The intra- 


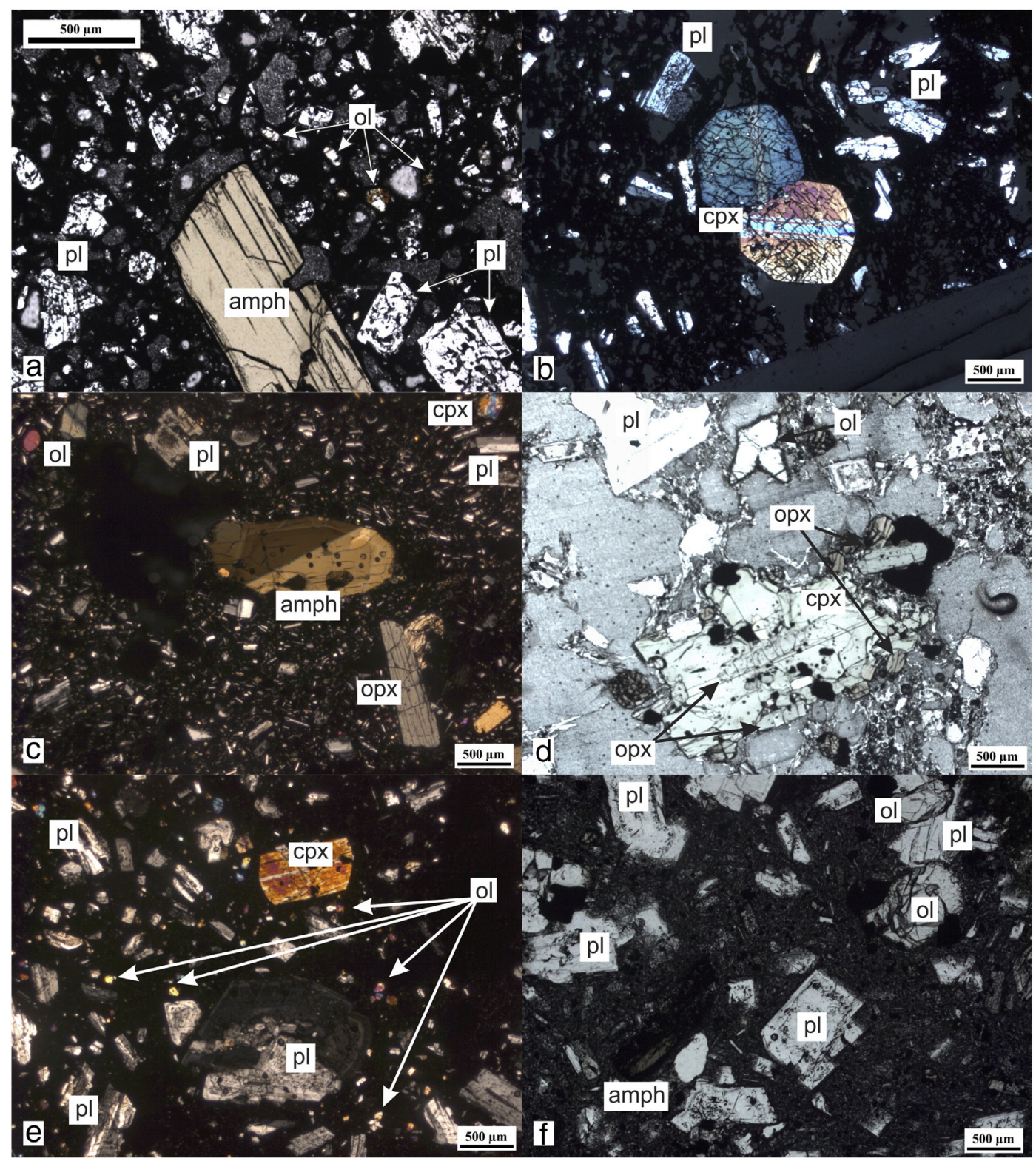

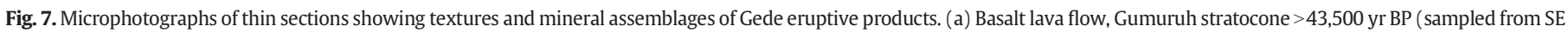

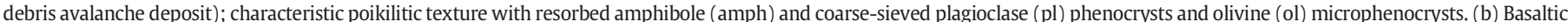

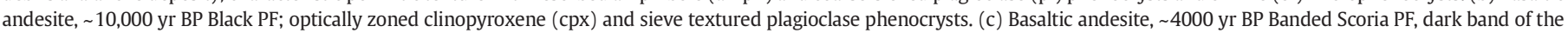

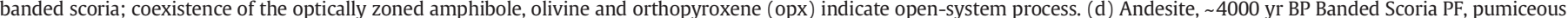

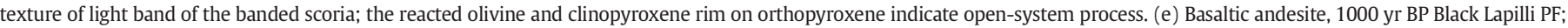

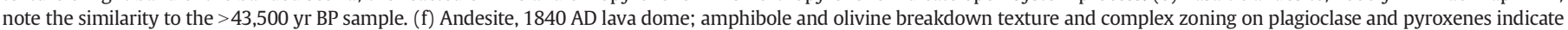
open-system processes. The calibrated ${ }^{14} \mathrm{C}$ ages are rounded to the nearest thousand (see Fig. 3 ).

crater lava has large aggregates of olivine, plagioclase and pyroxenes. The varied mineralogy, their complex zoning, and reaction textures of the minerals also indicate that the andesites are the result of interactions of magmas of contrasting compositions.

\section{Discussion}

\subsection{Reconstruction of eruptive history of Gede}

\subsubsection{Middle-Late Pleistocene}

The available data on the geology of Gumuruh edifice indicate that the first period of the volcano's history was characterized by dominantly effusive eruptions with deposition of thick blocky lava flows (exposed in the deposit of the SE debris avalanche). This period of activity produced the most mafic magmas we have sampled. Their mineralogical characteristics (presence of amphibole) imply rather high water contents (about 5 wt.\%) (e.g., Sisson \& Grove, 1993). However we did not find the pyroclasts associated with those eruptions, so we suppose that most volatiles escaped non-explosively while the magma was still rising. The magmas appear to be a possible parent for differentiation of the high-Al basaltic andesites which erupted later on (Fig. 8).

Major events during later period of Gumuruh were a large-scale $\left(>10 \mathrm{~km}^{3}\right)$ lateral gravitational collapse toward the SE, and some time later (when the edifice was completely rebuilt) formation of the $1.8-\mathrm{km}$-wide summit caldera. The caldera was formed by vertical subsidence perhaps due to a voluminous flank eruption of lava.

The first post-caldera eruptions were moderately explosive and possibly phreatomagmatic. During this period, a thick sequence of 


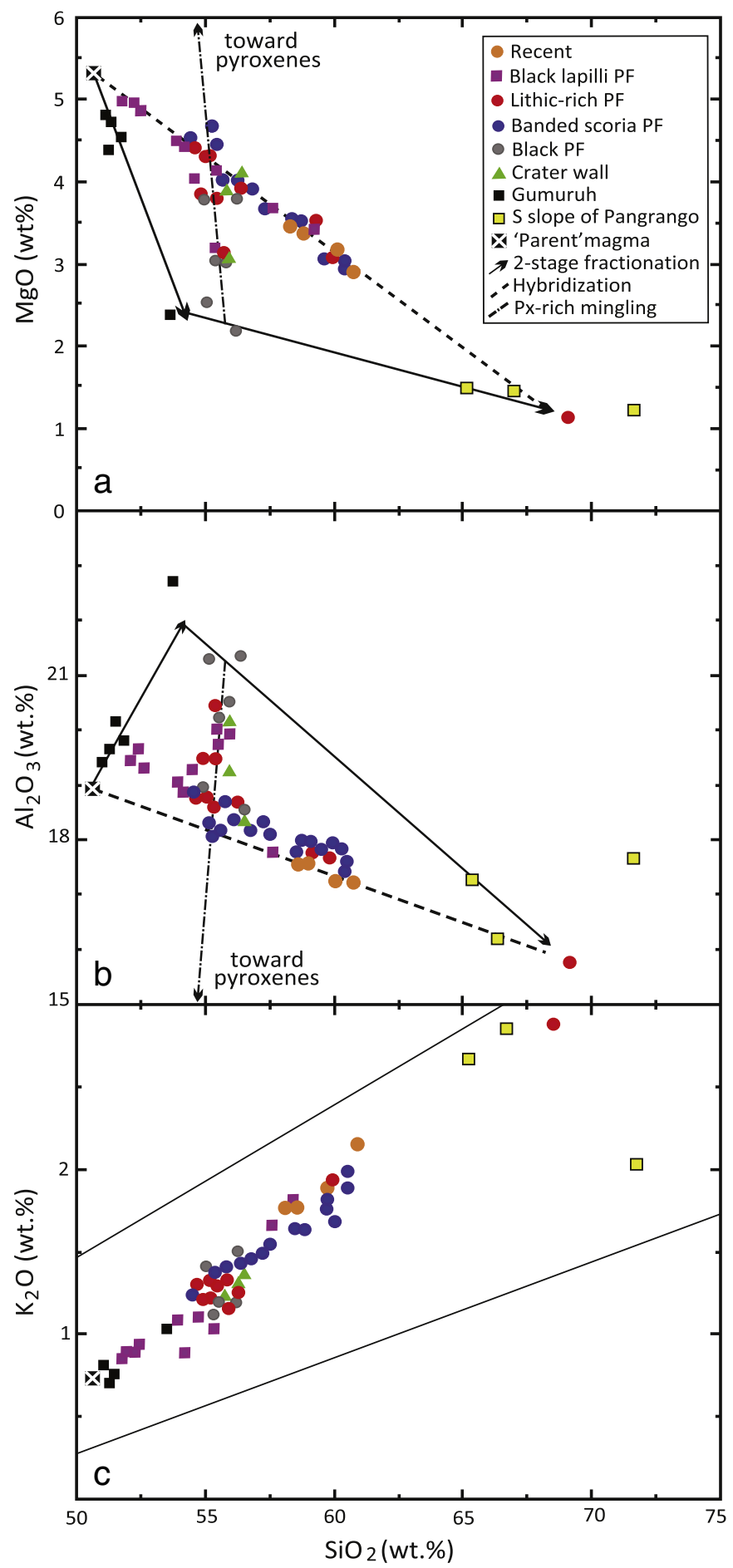

Fig. 8. Harker diagrams of bulk-rock compositions of calc-alkaline series of Gede eruptive products. Modeled magmatic processes are indicated by lines and arrows. The mineral assemblage of the basaltic samples of the $>43,500 \mathrm{yr}$ BP unit indicates two stage fractionation: olivine, amphibole, and clinopyroxene represent the first stage; Ca-rich plagioclase, olivine, and subordinate apatite, zircon, and potassic feldspar comprise the second stage. Xenocrystic evolved cores of reversely-zoned 10,000 yr BP pyroxenes show the pyroxene-rich mingling. Banded-scorias, complex zoning pattern of phenocrysts indicates the mixing between primitive basaltic and rhyodacitic components. Detailed petrologic and geochemical study is to be published by Krimer et al.

lahars and PFs was deposited in the NE sector of the volcano ring plain (the northern part of the caldera wall forms the lowest point on the rim). These deposits are strongly weathered and poorly exposed, and thus were not studied in detail and not described in this paper. One of the youngest PFs of that period was emplaced $>43,500 \mathrm{yr}$ BP.
After that several thick lava flows formed the intra-caldera cone of Gede. We do not have direct data on the age of the lava cone. However, its lavas have compositional and mineralogical features very similar to the juvenile material of the $10,000 \mathrm{yr}$ BP Black PF (Fig. 8). Thus, the lavas and the PF could have been erupted close in time sequence on the boundary between the Pleistocene and Holocene. From this we conclude that at the end of the Pleistocene (before formation of the lava cone) the volcano had a period of repose $>30,000$ years.

\subsubsection{Holocene}

Holocene volcanic activity was dominantly explosive. Volumetrically significant eruptions were relatively rare and of moderate violence (highest VEI 3-4; largest volume of erupted pyroclastic deposits $0.15 \mathrm{~km}^{3}$ ). There were 4 major eruptive episodes at approximately $10,000,4000,1200$, and 1000 yr BP (Figs. 2b and 3). We have not found extensive voluminous coarse-grained deposits of fallout tephra around the volcano, suggesting that the eruption plumes were not buoyant. Thick and coarse layers of tephra and ballistics were deposited only in close proximity to the vent, while most of the erupted products were transported in the form of highly concentrated valley-channelized pyroclastic flows. The only exception is the highly mobile PDC deposited on the southern slope of Pangrango $1200 \mathrm{yr}$ BP.

The first major Holocene eruption of Gede occurred ca. 10,000 yr BP. It was relatively explosive, voluminous, and probably purely magmatic. It deposited several thick agglutinated layers of proximal fallout around the vent as well as voluminous Black PF. The PF filled deep paleo-valleys of the NNE slope formed during the preceding period of dormancy. This eruption probably formed the 900 -m-wide summit crater of Gede. The erupted magmas are basaltic andesites that could have been differentiated from the basaltic magma like that which built the Gumuruh stratocone. Moreover, we also see microscopic (reverse zoning) petrologic evidence for mingling between mafic melts and more evolved pyroxenes that grew from a higher silica magma (possibly rhyodacite). This suggests that by this time a high-silica magma reservoir existed below Gede.

We speculate that after the formation the summit crater became a wet environment possibly filled with a crater lake, owing to very humid climate of the area. Thus, next two significant eruptions at 4000 and $1200 \mathrm{yr}$ BP could occur through a crater lake. Their products (the Banded Scoria PFs, the Lithic-rich PFs) indicate that these eruptions were of wet phreatomagmatic mechanism: relatively low depositional temperatures indicated by partial charring of the picked-up wood, high proportion of non-juvenile clasts, poorly vesicular juvenile material, and cauliflower bombs. Several voluminous lahars deposited in that period could have been fed by water from the crater lake. The magmas erupted during these periods are significantly more evolved, ranging from basaltic andesite to dacite in composition (Fig. 8). Moreover, we have found evidence of mingling and mixing between evolved melts in shallow silicic reservoir and mafic magmas coming from greater depth. The mineralogy of the magmas shows amphibole was stable and thus the minimum water contents were approximately $3 \mathrm{wt} . \%$ and minimum depth of the silicic reservoir was about $4 \mathrm{~km}$ based on phase equilibrates (see following section). The recurrent evidence of partially mingled scoria suggests that intrusion of mafic magma may have occurred shortly before eruptions and perhaps was a trigger.

Then at ca. 1100-1000 yr BP the crater wall gravitationally collapsed outward in two episodes that deposited correspondingly the Black Lahar and the NE Debris Avalanche. As a result the inferred crater lake drained. Subsequently, a dry magmatic eruption occurred ca. $1000 \mathrm{yr}$ BP and deposited the Black Lapilli PF. Magmas erupted during this period show a large range of compositions and overlap with almost all previously erupted ones. We also see evidence of mixing and mingling as in the previous units and thus similar magmatic processes were occurring during this period. The main difference is that the magmas from this period do not have amphibole; this could reflect lower water content in the melt and/or lower pressure of storage and thus a shallower reservoir. 
Recent eruptive period (during last 800 years the volcano history) was characterized by frequent weak (VEI 1-2) explosive eruptions depositing thin layers of fine-grained lithic ash layers. The ash falls that produced these layers were limited to areas within the proximal volcano ring plain, indicative of relatively low-altitude eruptive ash columns. In 1840, the intra-crater lava flow/dome was extruded. The most recent eruptions of Gede represented series of weak sporadic phreatomagmatic explosions akin to Vulcanian type in a broad sense (according to the definition given in Clarke et al., 2015). These eruptions were probably associated with small-volume intrusions of magma into the shallow hydrothermal system of the volcano. The eruptions formed several small explosive craters on top of the 1840 lava dome. Some of the explosions were strong enough to launch large ballistics to the Alun-Alun area to distances up to $1 \mathrm{~km}$ from the vent. The magmas during these last episodes are andesites that show also evidence for mixing and mingling of mafic and silicic components. The presence of amphibole in the deposits suggests higher water contents than in the 1000 yr BP eruption.

\subsection{Evolution of magma reservoir and magmatic processes}

The erupted magmas form a medium-K (Fig. 8c) calc-alkaline series except for the $>43,500 \mathrm{yr}$ BP lavas of Gumuruh that fall in the tholeiitic field. The series is compositionally continuous for the mafic end, but a compositional gap of 7 wt.\% exists between 62 and 69 wt.\% $\mathrm{SiO}_{2}$. Major and trace element models of the bulk rocks together with detailed mineralogical observations show that there are multiple episodes of fractional crystallization and mixing/mingling events recorded in the Gede eruptive products (Fig. 8). A two-stage waterrich differentiation of Gumuruh ( $>43,500 \mathrm{yr} \mathrm{BP}$ ) magmas from basalt to basaltic andesite involves plagioclase-free fractionation of olivine, clinopyroxene, amphibole, and spinel. This leads to the production of high-alumina basaltic andesites. Further differentiation from basaltic andesite to rhyodacite appears to occur under drier conditions and requires plagioclase, two pyroxenes, olivine, magnetite, and subordinate amount of apatite, alkali feldspar and zircon.

Linear trends of the basaltic andesites and andesites (i.e., $4000 \mathrm{yr} \mathrm{BP}$ and onwards) as seen in variation diagrams (Fig. 8) can be explained by mixing and mingling between basaltic and rhyodacite end-members, or fractionation of a hybrid mafic magma. Almost all samples show textural and mineralogical evidences of mixing and mingling. Detailed petrological analyses (to be published separately) show that in fact some of the basaltic andesites represent also one of the mafic end-member that was involved in the mixing and which led to the creation of the andesites. Another type of magma mingling occurs between the lowmagnesium basaltic andesite and a crystal-rich part of the silicic reservoir. Addition of pyroxenes to the magma can explain some of the range in composition shown by the basaltic andesites (e.g., $10,000 \mathrm{yr} \mathrm{BP}$ ) and is consistent with their high modal proportions of pyroxenes (Fig. 8).

Amphibole (mainly pargasite) is present in almost all deposits, and its stability requires at least $3 \mathrm{wt} . \%$ of water in the melt (Rutherford and Devine, 2003; Costa et al., 2004). Moreover, for the magmas for which we infer a plagioclase absent and amphibole present fractionation, it implies water contents of at least 5 wt.\% in the melt (Sisson and Grove, 1993). Assuming volatile saturation and water solubility models (Newman and Lowerstern, 2002) we obtain a pressure of 140-240 MPa, which suggests a depth of the magma reservoir between 4 and $8 \mathrm{~km}$ below the summit of Gede. Textural and mineralogical observations (that suggest open system processes including mixing and mingling between magmas, or between magmas and crystal-rich zones) indicate that intrusion of mafic magma in a crystal-rich silicic reservoir is a common process at Gede. Perhaps the periodic seismic crises recorded below Gede in the last 20 years or so reflect the intrusion of mafic magmas.

\subsection{Implications of future activity}

The volumes of the eruption products of Gede we have estimated are approximate; however, during the Holocene our estimates suggest that the volcano produced about $1 \mathrm{~km}^{3}$ of various primary deposits (dominantly pyroclasts). Taking into account high percentage of nonjuvenile material in the deposits, and the density differences between the magma and vesicular juvenile pyroclasts, we can roughly estimate that Gede erupted $\sim 0.3 \mathrm{~km}^{3}$ of magma during last 10,000 years, or on average $\sim 30,000 \mathrm{~m}^{3}$ of magma per year. Such small productivity suggests that the likelihood of future large-volume (VEI $\geq 5$ ) eruption of the volcano is low. For example, the strongest eruptions of the volcano in the Holocene were of VEI 3-4 with up to $0.15 \mathrm{~km}^{3}$ of ejected pyroclastic material - this is realistic upper limit of parameters for the next significant eruption. However, despite relatively small volumes, most of the erupted pyroclasts were transported in the form of pyroclastic flows that were able to travel more than $12 \mathrm{~km}$ downslope to elevations $<800$ masl. Similar eruptions in the future would have devastating consequences for the now densely populated region. The topography of Gede Volcano's summit area would probably focus the majority of the erupted flowage material toward the NNE - that sector of the volcano ring plain will be the most dangerous.

The recent period of the volcano history was characterized by frequent weak VEI 1-2 phreatomagmatic explosive eruptions. These eruptions produced vertical ash clouds less than a few $\mathrm{km}$ high with ballistic fallout in proximal summit area and limited weak ash falls around the volcano foot. This is the most probable scenario for the future eruption of minor scale. Extrusion of thick blocky lava flows/ domes is also possible.

The volcanic edifice of Gede is not exceptionally high or steep and the hydrothermal alteration/weakening of the rocks on the upper slopes appears to be of limited extent. Thus, large-scale gravitational collapse of the edifice is of low probability. However, approximately $0.01 \mathrm{~km}^{3}$ remnant of the NNE crater rim (Rock Sela) is gravitationally unstable and could collapse during the next eruption or large earthquake.

Mafic magma recharges into the shallow silicic reservoir certainly occurred shortly before all Holocene eruptions of Gede and might be their trigger. Perhaps geophysical signals (e.g., a seismic swarm, inflation of edifice) that may indicate such intrusion will precede the next eruption. Monitoring of such signals is recommended in order to forecast future eruptions.

\section{Conclusions}

Our investigations have shown that the giant edifice of Gede Volcano with the volume of the order of $100 \mathrm{~km}^{3}$ was constructed mostly in the Pleistocene. Petrological data indicate that by the end of that period a silicic magma reservoir existed below the volcano. Then a repose period with little if any eruptive activity followed, during which the magma reservoir underwent substantial crystallization. Activity of Gede suddenly resumed at the Pleistocene/Holocene boundary. The new cycle of activity turned out to be much less productive - the Holocene deposits, with a total volume of only $1 \mathrm{~km}^{3}$ formed a thin localized veneer over the strongly weathered Pleistocene deposits. Geological and petrological data indicate that the Holocene eruptions were associated with intrusions of small-volume batches of mafic magma into the crystal-rich silicic reservoir.

Repose periods longer than several thousand years are rare for subduction related volcanoes (Szakacs, 1994). The repose $>30,000$ years long seems to be an exceptional case, although we can't rule out the possibility that we have not found the deposits of some small eruptions. Being inactive for so long period, Gede by the end of the Pleistocene was practically extinct. However, 10,000 years ago its magma reservoir was revitalized by periodic intrusion of small batches of mafic magma rising from a deeper source. 
Until now there are few volcanological data on how volcanoes behave after exceptionally long repose periods. The common opinion, for instance, is that the longer repose period, the more violent will be following eruption. However, the post-repose eruptions of Gede were of rather mild scale. The long repose period and the small erupted volume during the Holocene could be interpreted as if Gede represents a volcano on its final stage of activity: with time its activity might gradually decline and the volcano became extinct. However, the recurrent seismic swarms and relatively silica-rich magmas erupted during the Holocene suggest that there might be a silicic magma reservoir that could be destabilized by the ongoing intrusions of mafic magma, and activity of the volcano could suddenly increase up to strong explosive eruption. This would have major societal and economic impacts given the high density of population around Gede and its proximity to Indonesian capital, Jakarta. Thus, Gede provides the unique opportunity to study various volcanological aspects of behavior of a subduction related volcano reawakened after exceptionally long repose period.

Supplementary data to this article can be found online at http://dx. doi.org/10.1016/j.jvolgeores.2015.05.018.

\section{Acknowledgments}

We thank CVGHM staff for their support during field works, Chris Newhall for support and discussions, and Christina Widiwijayanti for summarizing the data about historical activity of Gede. The paper was improved by careful review from John Pallister and Heather Wright. Research was supported through Gede Laboratory volcano project (Singapore NRF, \#M4430151.B50.706022).

\section{References}

Clarke, A.B., Ongaro, T.E., Belousov, A., 2015. Vulcanian eruptions, chapter 28. In: Sigurdsson, H., et al. (Eds.), Encyclopedia of Volcanoes, 2nd Edition, pp. 505-518.

Costa, F., Scaillet, B., Pichavant, M., 2004. Petrological and experimental constraints on the pre-eruption conditions of Holocene dacite from Volcan San Pedro ( $36^{\circ} \mathrm{S}$, Chilean Andes) and the importance of sulphur in silicic subduction-related magmas. J. Petrol. 45, $855-881$.

Davidson, J., Turner, S., Handley, H., Macpherson, C., Dosseto, A., 2007. Amphibole "sponge" in arc crust? Geology 35, 787-790.

Dempsey, S.R., 2013. Geochemistry of Volcanic Rocks From the Sunda Arc (PhD theses), Durham University (280 pp.).

Hadisantono, R.D., Abdurachman, E.K., Martono, A., Sumpena, A.D., Wahyu, S., Santoso, M.S., 2006. Volcanic hazard map of Gede Volcano, West Java Province. Center for Volcanology and Geological Hazard Mitigation, Bandung. Scale 1:50,000.
Handley, H.K., Macpherson, C., Davidson, J.P., 2010. Geochemical and Sr-O isotopic constraints on magmatic differentiation at Gede Volcanic Complex, West Java, Indonesia. Contrib. Mineral. Petrol. 159 (6), 885-908

Handley, H.K., Turner, S., Macpherson, C.G., Gertisser, R., Davidson, J.P., 2011. Hf-Nd isotope and trace element constraints on subduction inputs at island arcs: limitations of Hf anomalies as sediment input indicators. Earth Planet. Sci. Lett. 304 (1), 212-223.

Hidayat, D., Basuki, A., Budianto, A., Triastuty, H., Marcial, S.S., Mathovani, A., Schwandner F.M., Kunrat, S., Mulyana, I., 2012. Tectonics or Magma Intrusion? - New Results from Multi-parameter Study at Gede Volcano, West Java, Indonesia. AOGS Abstract, Singapore.

Junghuhn, F., 1856. Java-Album. Landschafts-Ansichten von Java. Arnoldische Buchhandlung, Leipzig.

MacLeod, N., 1989. Sector-failure eruptions in Indonesian volcanoes. Geol. Indones. 12 563-601.

Neumann van Padang, M., 1951. Indonesia. Catalog of active volcanoes of the world and Solfatara Fields, Rome. IAVCEI 1, 1-271.

Newhall, C., Self, S., 1982. The Volcanic Explosivity Index (VEI): an estimate of explosive magnitude for historical volcanism. J. Geophys. Res. 87, 1231-1238.

Newman, S., Lowerstern, J.B., 2002. VolatileCalc: a silicate melt- $\mathrm{H}_{2} \mathrm{O}-\mathrm{CO}_{2}$ solution model written in Visual Basic for Excel. Comput. Geosci. 28 (5), 597-604.

Petroeschevsky, W.A., Klompe, H.F., 1951. Vulcanological Investigations in Indonesia 23. OSP Publication, Bandung, Indonesia (17 pp.).

Rutherford, M.J., Devine, J.D., 2003. Magmatic conditions and magma ascent as indicated by hornblende phase equilibria and reactions in the 1995-2002 Soufriére Hills magma. J. Petrol. 44, 1433-1453.

Siebert, L., Simkin, L., Kimberly, P., 2010. Volcanoes of the World. Third edition. Smithsonian Institution, Washington, D.C., pp. 87-88.

Sisson, T.W., Grove, T.L., 1993. Experimental investigations of the role $\mathrm{H}_{2} \mathrm{O}$ in calc-alkaline differentiation and subduction zone magmatism. Contrib. Mineral. Petrol. 113, 143-166.

Situmorang, T., Hadisantono, R.D., 1992. Geologic Map of Gede Volcano, Cianjur, West Java. Volcanological Survey of Indonesia. Scale 1:50,000.

Small, C., Naumann, T., 2001. The global distribution of human population and recent volcanism. Environ. Hazards 3, 93-109.

Streck, M.J., 2008. Mineral textures and zoning as evidence for open-system processes Rev. Mineral. Geochem. 69, 595-622.

Suantika, G., Rochendi, D., Wahyongko, K., Lius, L., 1999. Evaluasi seismic atau kegempahan Gunagapi Gede Tahun 1985-1999. Direktorat Vulkanologi project report (23 pp.).

Szakacs, A., 1994. Redefining active volcanoes: a discussion. Bull. Volcanol. 56, 321-325.

Taverne, N.M.J., 1926. Vulkaanstudien Java: Vulkanol. Seismol. Meded. 7, 84-90.

Van Bemmelen, R.W., 1949. The Geology of Indonesia Vol. 1A. Government Printing Office, The Hague (732 pp.).

Verbeek, R.D.M., Fennema, R., 1896. Geologische beschrijving van Java en Madoera vol. 2 pp. 741-748 (Amsterdam)

Winter, J.D., 2001. An Introduction to Igneous and Metamorphic Petrology. Prentice Hall, $\mathrm{NJ}$ (304 pp.).

Zaennudin, A., 2008. Report of reconnaissance monitoring of Gunung Gede in 2007 Unpubl. CVGHM report, (21 pp.) 